\title{
Dinar-Bademli Cami: Mimari Özellikleri ve Kalem İșleri
}

\author{
Dinar-Bademli Mosque: Architectural Characteristics and Hand-Made Decorations on Plaster
}

\author{
다 Aslıhan Ece PAKÖZ,' 다 Nurcan BOŞDURMAZ, ${ }^{2}$ ○ Zeynep Gül ÜNAL ${ }^{3}$
}

ÖZ

Afyonkarahisar'ın Dinar ilçesi, Bademli Köyü'ndeki Bademli Cami Geç Osmanlı dönemine tarihlenmektedir. Anadolu'da birçok şehirde olduğu gibi Afyonkarahisar'da da bu dönem etkileriyle bezenmiş camiler vardır. Bademli Cami yoğun bir bezeme programına sahip olması ve bezemelerinin özgün niteliklerini koruması açısından önemli bir örnek teşkil etmektedir. Ahşap direkli, düz ahşap tavanlı bu caminin kârgir duvarları sıva üzerine renkli kalem işleriyle bezenmiştir. Bunlar arasında en dikkat çeken kalem işi son cemaat yerindeki Sultan II. Abdülhamid'in tuğrasıdır. Bunun yanı sıra caminin giriş kapısından içeriye doğru devam eden yazı programı, 20. yüzyıl başında mekândaki ibadetin sembolik yansımasının nasıl algılandığını göstermesi açısından önemlidir. Caminin mimari özellikleri ile beraber çeşitli süslemelerden oluşan kalem işleri bu çalışmanın konusunu oluşturmaktadır. Çalışmada; hem bakım ve onarım eksikliğine hem de kullanıma bağlı koruma sorunları yaşayan Bademli Cami'nin sahip olduğu özgün niteliklerin korunması için koruma önerileri de verilmektedir. Bu konuda makale yazarları tarafından 2018 yılında hazırlanan koruma projesinden yararlanılmıştır.

Anahtar sözcükler: Bademli Cami; Dinar; kalem işi; mimari özellik; tuğra.

\section{ABSTRACT}

Bademli Mosque, in Bademli village of Afyonkarahisar, dates back to the late Ottoman period. In Afyonkarahisar, as in many other Anatolian cities, the influence of this period is visible in the adorning of mosques. Bademli Mosque is an important example as it has an extensive decoration program and preserves its original features. The mosque has timber posts and a flat roof, clad with timber. Its walls are adorned with colorful handmade decorations on plaster, the most noticeable one being Sultan Abdülhamid II's tughra in the last prayer hall. In addition, the calligraphy program that extends inward from the entrance of the mosque is remarkable in that it shows how the symbolic reflection of worship in the place was perceived at the beginning of the 20th century. The present study focuses on the mosque's rich handmade decorations, as well as its architectural characteristic. The study also provides suggestions for the preservation of the unique features of the Bademli Mosque, which have been poorly protected due to user-related problems and a lack of maintenance and repair. In this context, preservation project proposed by the authors in 2018 was used as a reference.

Keywords: Bademli Mosque; Dinar; handmade decoration; architectural characteristic; tughra.

'İstanbul Şehir Üniversitesi Mimarlık ve Tasarım Fakültesi, Mimarlık Anabilim Dalı, İstanbul 2istanbul Bilgi Üniversitesi, Genel Eğitim Bölümü, İstanbul

${ }^{3}$ Yıldız Teknik Üniversitesi Mimarlık Fakültesi, Mimarlık Anabilim Dalı, İstanbul

Başvuru tarihi: 19 July 2018 - Kabul tarihi: 04 May 2019

İletişim: Aslıhan Ece PAKÖZ. e-posta: aslihanecepakoz@sehir.edu.tr

๑ 2020 Yıldız Teknik Üniversitesi Mimarlık Fakültesi - ๑ 2020 Yıldız Technical University, Faculty of Architecture 


\section{Giriş}

Ege Bölgesinde Afyonkarahisar ilinin Dinar ilçesine bağlı olan Bademli Köyü; Aydınlı, Orta ve Camili olmak üzere üç mahalleden oluşmaktadır (Şekil 1). Bu çalışmada incelenecek olan Bademli Camisi, Camili Mahallesi'nde bulunmaktadır (Şekil 2).

Sahip olduğu mimari nitelikler nedeniyle korunması gerekli kültür varlığı olarak tescillenerek koruma altına alınan Bademli Camisi'nin yapım yılı ile ilgili kesin bir bilgi bulunmamaktadır. ${ }^{1}$ Ancak yap üzerinde tarihlendirmeye olanak sağlayabilecek iki adet kitabe vardır. Bunlardan erken tarihli olanı, kuzey cephede giriş kapısının üzerindeki kalem işi kitabedir. Zaman içinde kitabenin üzeri boyanmış olmakla birlikte izlerden tarih okunabilmektedir (Şekil 3). Kitabe H. 1317 (Miladi 1900) tarihlidir. Bu kalem işi kitabe ile caminin iç duvarlarında bulunan kalem işlerinin aynı özellikleri taşımasından dolayı, bu tarihin caminin yapım tarihi olması kuvvetle muhtemeldir. Yapının üzerinde yer alan daha geç bir tarih, güney cephesi üzerindeki pencerenin kemer taşına oyulmuştur (Şekil 4). Bu kitabeden ise H. 1338 (Miladi 1920) tarihi okunmaktadır. Bu tarihin yapının onarım tarihini gösteren bir tarih olması çok olası değildir, çünkü onarım tarihleri yapıların ön cephesindeki bir yerde, yani daha görünür yerlerdedir. Elbette, 1919-1922 yılları arasında İstiklâl Harbi'nin olduğu da dikkate alınırsa bu tarihin onarım tarihi olması oldukça düşük bir olasılıktır. Yapının üzerinde yer alan ve caminin yapım tarihi ile ilgili bilgi verebilecek bu iki yazılı bilgi dışında, caminin son cemaat yeri duvarında bulunan bir kalem işi Osmanlı arması da yapının tarihi ile ilgili fikir verebilir. 19. yüzyılın ikinci yarısında inşa ya da tamir edilen her resmî yapının cephesinde yer alan ve Osmanlı İmparatorluğu'nu her yerde temsil eden bu armalar, son şeklini II. Abdülhamid döneminde (1876-1909) almıştr. Caminin giriş kapısının üzerindeki kalem işi kitabede yazan H. 1338 (Miladi 1920) tarihi ile 1876-1909 yılları arasında tahtta olan Sultan II. Abdülhamid'in saltanatının 25. yılı kutlamalarının aynı yıllara rastlaması, caminin söz konusu kutlamalar sebebiyle inşa edildiğini intimalini düşündürmektedir. Ancak bu konuda Osmanlı arşivinde herhangi bir belgeye rastlanılmamıştir.

\section{Mimari Özellikleri}

Plan Şeması: Bademli Camisi; son cemaat yeri, ana ibadet mekânı ve kadınlar mahfili olmak üzere üç mekândan oluşmaktadır. Ana ibadet mekânı kareye yakın planlı ve $11.43 \mathrm{~m}$ x12.02 m boyutlarındadır. Bu mekâna eklenmiş olan son cemaat bölümü $3.40 \mathrm{~m}$ enindedir. Zemin katta giriş kapısının iki yanında, zeminden yaklaşık $0.50 \mathrm{~m}$ yerden yükseltilerek oluşturulan bölümler de ana ibadet mekânına dahildir (Şekil 5). Bu bölümün üst katta bulunan

Bademli Köyü'nde 154 numaralı adada, 3 numaralı parselde kayıtlı bulunan Bademli Camisi'nin tescil işlemi Eskişehir Kültür ve Tabiat Varlıklarını Koruma Kurulu'nun 24.03.2000 tarih ve 1089 sayılı kararı ile yapılmıştır. kadınlar mahfiline çıkamayan kadınların ibadet etmesi için ayrıldığı tahmin edilmektedir. Ancak günümüzde az bir nü-

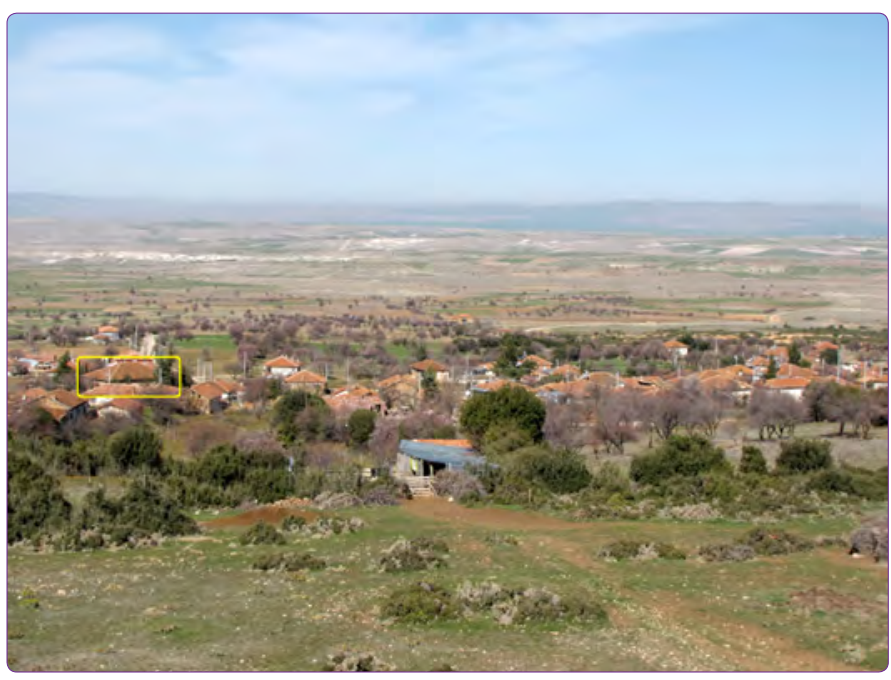

Şekil 1. Bademli Köyü (Fotoğraf: Zeynep Gül Ünal).

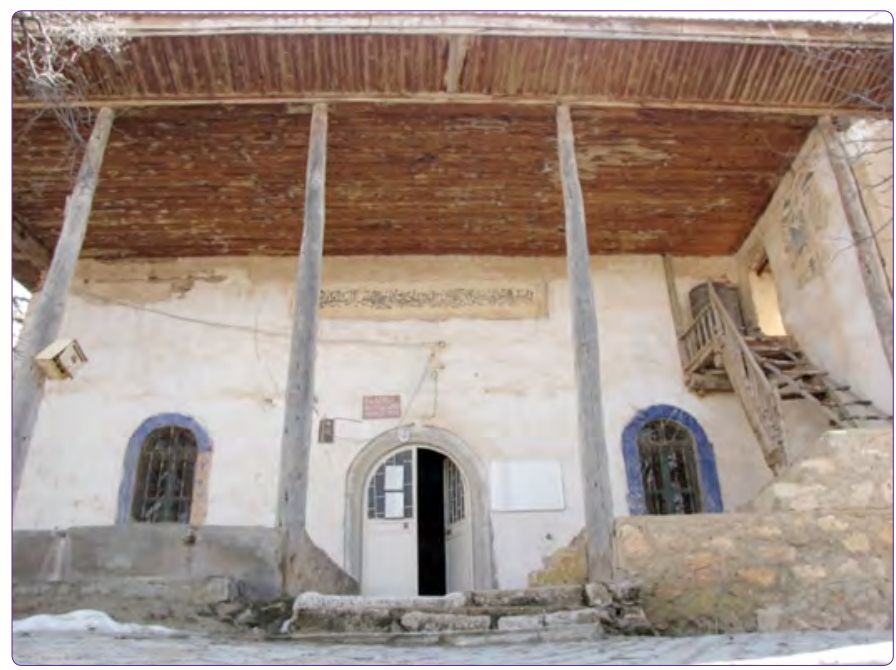

Şekil 2. Bademli Cami (Fotoğraf: Zeynep Gül Ünal).

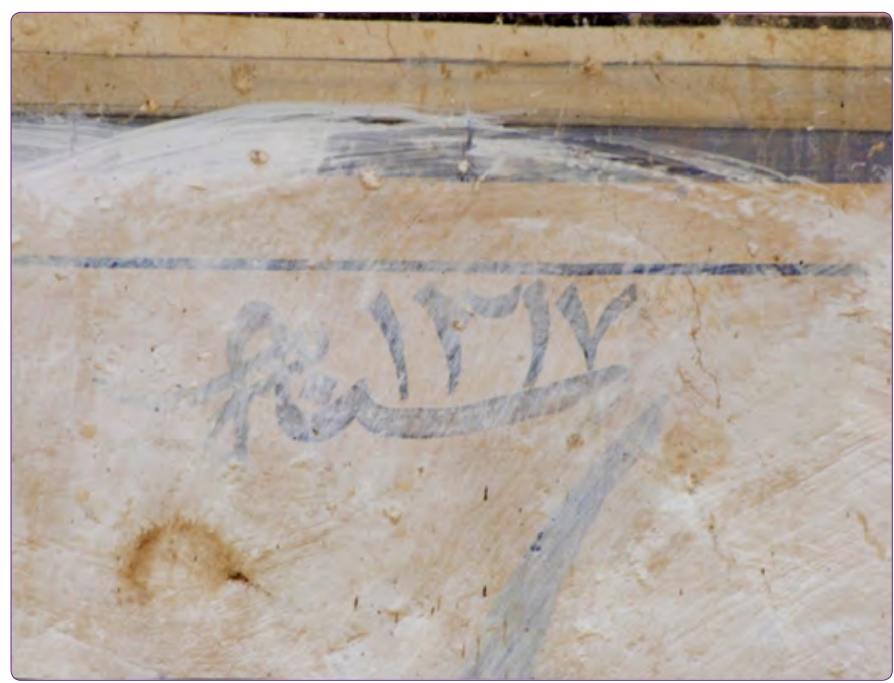

Şekil 3. Cami girişindeki kitabe (Fotoğraf: Zeynep Gül Ünal). 


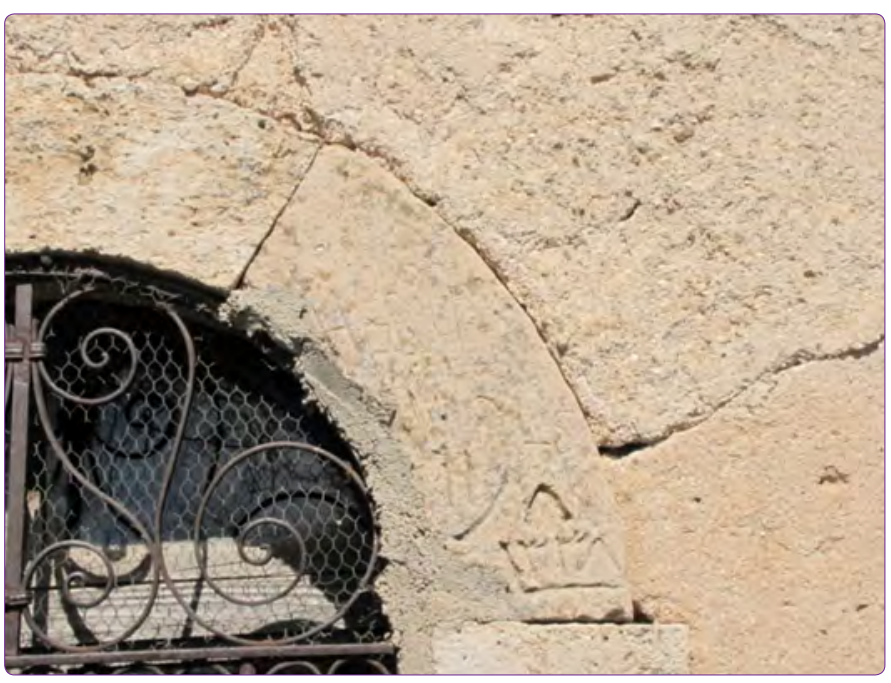

Şekil 4. Pencere kemer taşındaki kitabe (Fotoğraf: Zeynep Gül Ünal).

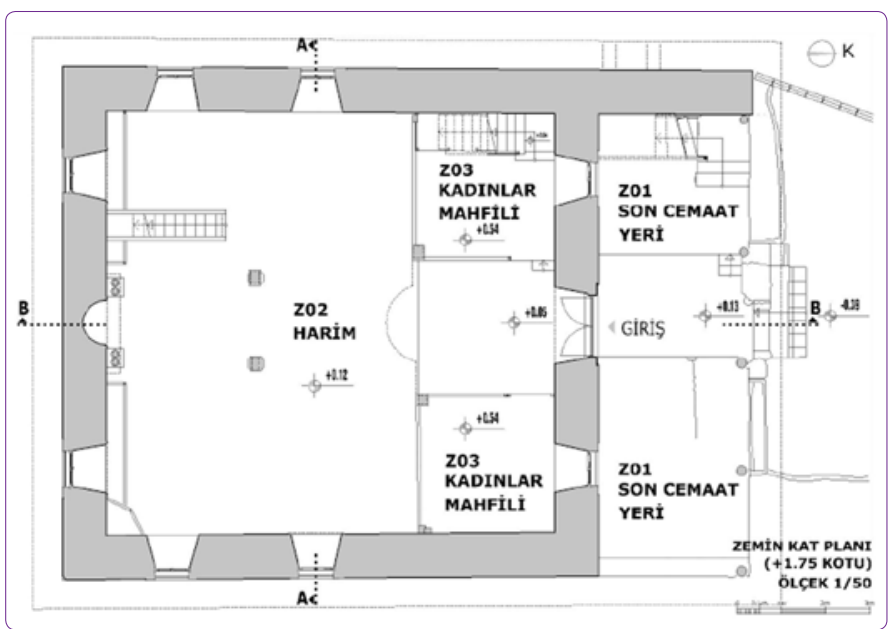

Şekil 5. Zemin Kat Planı (+1.75 kotu) (Çizim: Aslıhan Ece Paköz).

fusa sahip köyün, camiyi yoğun kullanacak bir cemaati de olmadığından bu bölümlerin kullanımı ile ilgili gözlemlere dayalı bir veri elde edilememiştir. ${ }^{2}$ Zemin kat döşemesinden 3.30 m yükseklikteki kısmi üst katta kadınlar mahfili bulunmaktadır. Bu mekâna ulaşım, dışarıdan son cemaat mahallinden bir ahşap merdivenle ve içeriden zemin kattaki zeminden yükseltilmiş bölümden diğer bir ahşap merdivenle sağlanabilmektedir (Şekil 6). Ana mekânın batı duvarında bulunan bezemelerin bir kısmı, üst kattaki kadınlar mahfiline ulaşımı bu sağlayan merdivenin altında kalmıştır (Şekil 7). Bu durum üst kattaki kadınlar mahfilinin yapıya sonrada eklendiğinin bir işareti olarak değerlendirilmektedir. Son cemaat mahallinden üst kata çıkışı sağlayan ahşap merdiven ise harap olmuştur ve günümüzde kullanılmaz durumdadır. Bu merdivenin sahanlığından batı cephesinde yer alan konsol bir balkona da çıkış vardır. Bu balkonun

\footnotetext{
231 Aralık 2019 tarihli Adrese Dayalı Nüfus Kayıt Sistemi sonuçlarına göre Bademli Köyü'nün nüfusu 317'dir (https://biruni.tuik.gov.tr/ medas/?kn=95\&locale=tr)
}

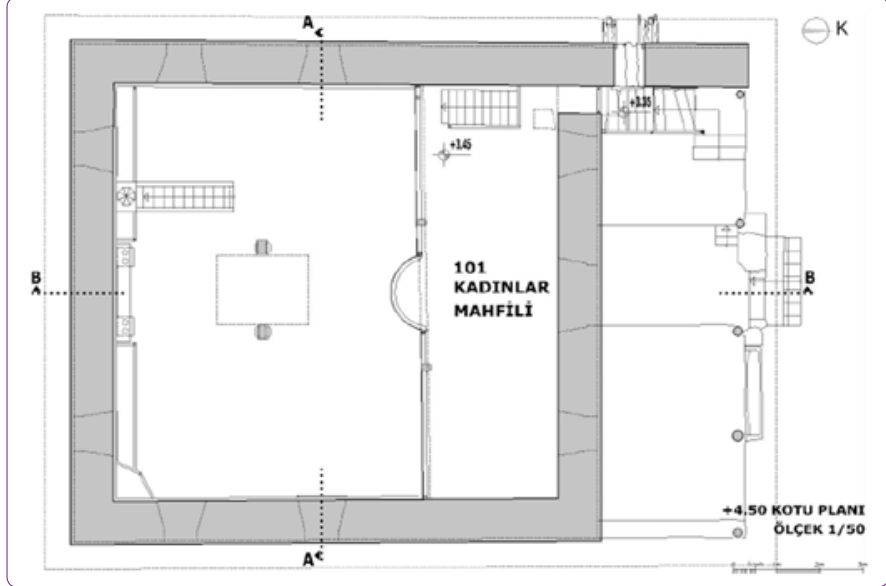

Şekil 6. Üst Kat Planı (+4.50 kotu) (Çizim: Aslıhan Ece Paköz).

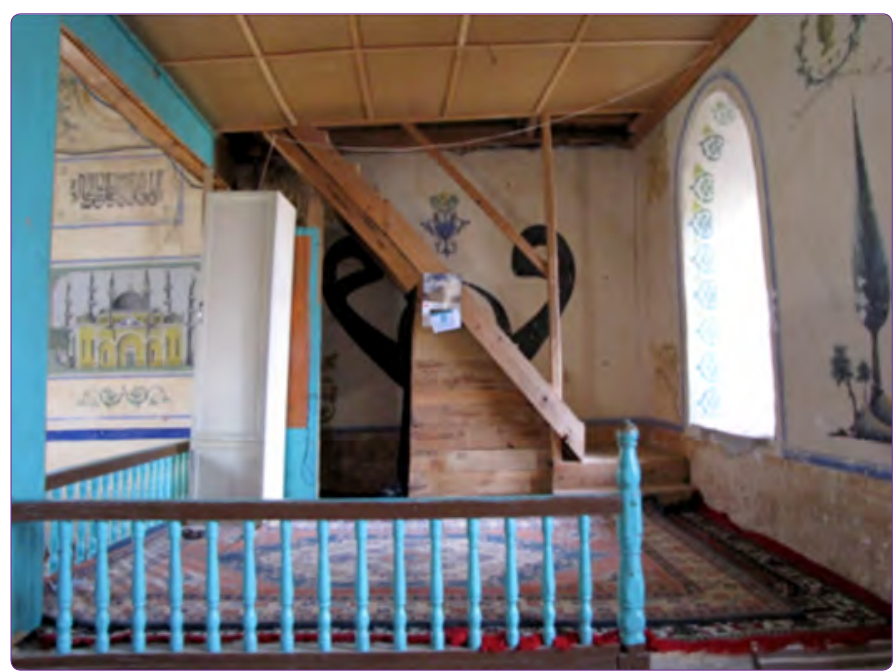

Şekil 7. Kadınlar mahfiline çıkış merdiveni (Fotoğraf: Zeynep Gül Ünal).

son cemaat mahalline değil de hazireye doğru yönlenmesinden dolayı, mükebbire olmadığı ve bir zamanlar müezzinin bu balkonu ezan okumak için kullandığı tahmin edilmektedir. Günümüzde bu balkona açılan kapının kanadı ve balkon döşemesi yok olmuştur. Balkonun sadece taşıyıcı ahşap kirişleri bulunmaktadır.

Ana mekânda tavan yüksekliği yaklaşık $5.12 \mathrm{~m}$, yapının zemini ile mahyası arasındaki yükseklik ise 7.83 m'dir.

Yapım Sistemi: Bademli Camisi, yığma kârgir sistemle inşa edilmiştir. Taş duvarların kalınlığı 98-100 cm'dir. Duvarlardaki dökülen sıvalardan taş duvarın yer yer ahşap hatıllarla desteklendiği görülmektedir. Yapı içinde üst örtüyü taşıyan iki adet ahşap dikme bulunmaktadır. Ayrıca kısmi birinci katı (kadınlar mahfili) taşımak için iki adet daha ahşap dikme vardır. Son cemaat bölümünün üst örtüsünü ise dört adet ahşap dikme taşımaktadır. Yapının üst örtüsü, ahşap kırma çatı sistemidir ve saz üzerine kiremit ile kaplanmıştır (Şekil 8, 9). Yapının taşıyıcı sistemini oluşturan malzemelerdeki derin çatlaklar dikkate alındığında taşıyıcı 


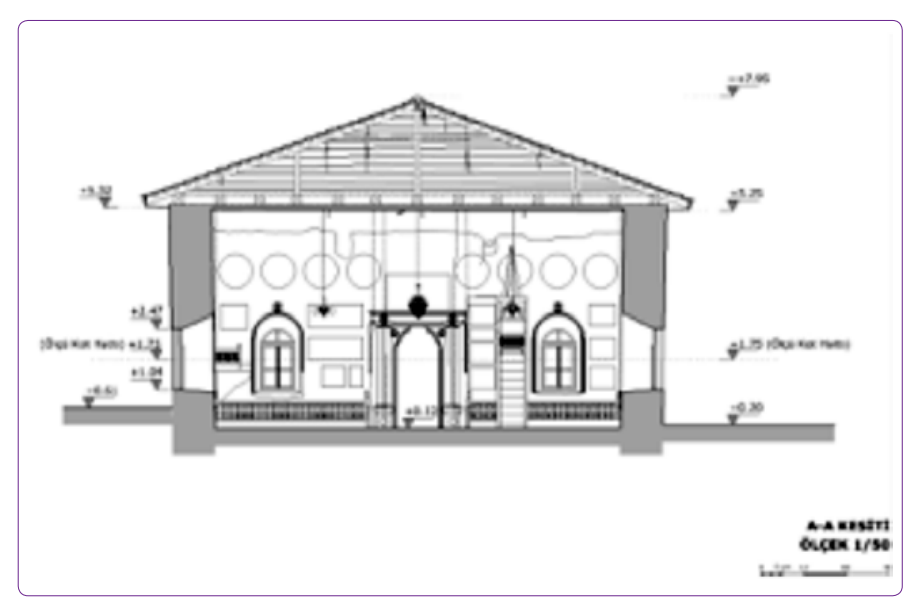

Şekil 8. A-A Kesiti (Çizim: Aslıhan Ece Paköz).

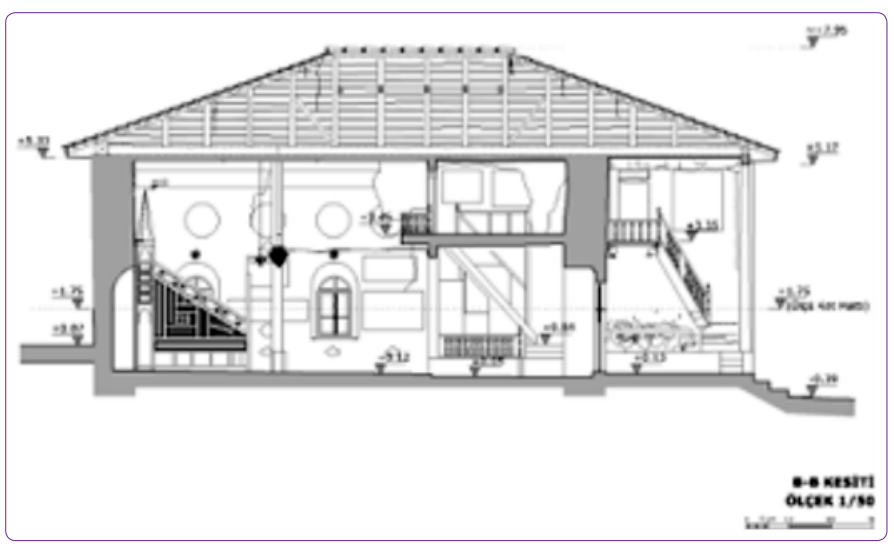

Şekil 9. B-B Kesiti (Çizim: Aslıhan Ece Paköz).

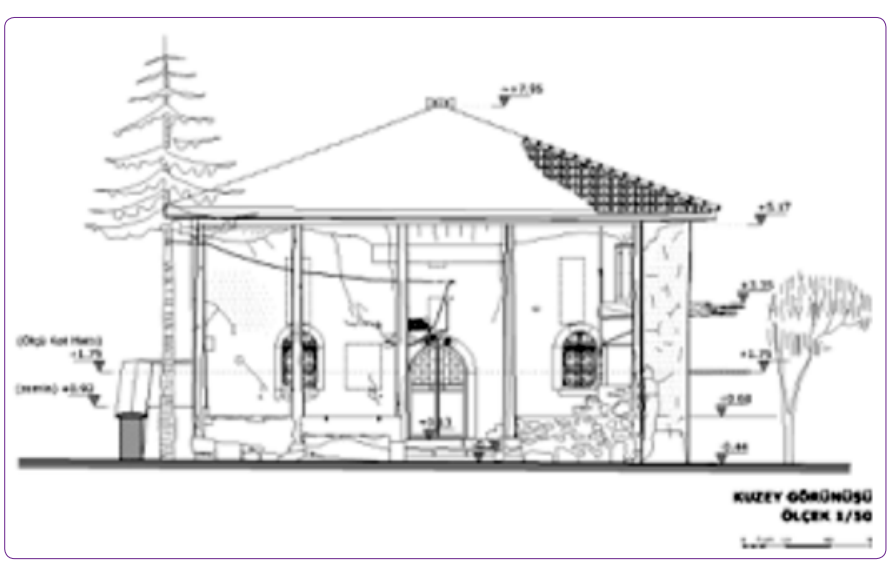

Şekil 10. Kuzey Görünüşü (Çizim: Aslıhan Ece Paköz).

sistemin en kısa zamanda iyileştirilmesi gerektiği anlaşılmaktadır.

Cephe Özellikleri: Yapının dört cephesinde de iki adet yarım kemerli pencere mevcuttur. Pencere kenarlarında dışta kesme taş söveler, içte alçı silmeler görülmektedir (Şekil 14, 15). Pencere doğramaları ahşaptır ve dışlarında metal parmaklıklar vardır. Giriş kapısı yarım yuvarlak kemerlidir ve kapı doğraması metaldir. Yapı içinde ve dışında cephelerde kıtkklı sıva kullanılmıştır. İç mekânda tüm duvar-

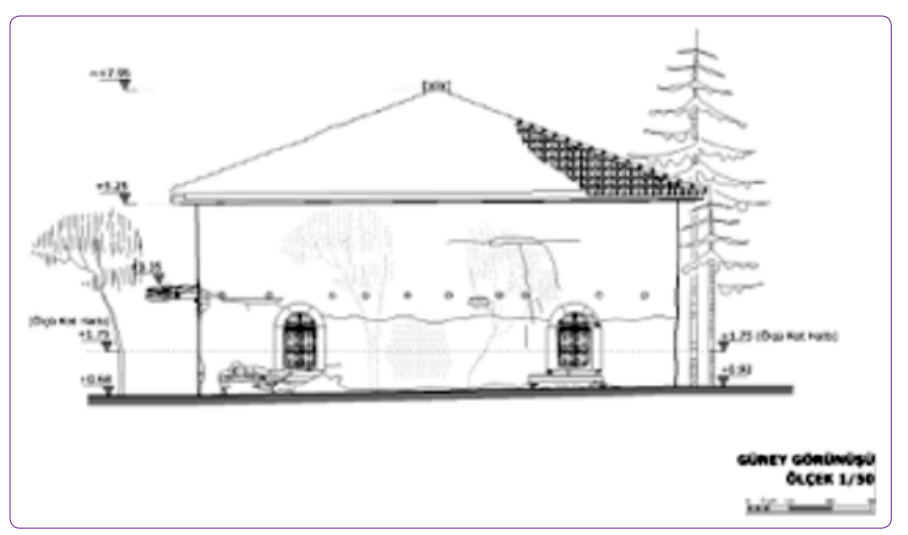

Şekil 11. Güney Görünüşü (Çizim: Aslıhan Ece Paköz)

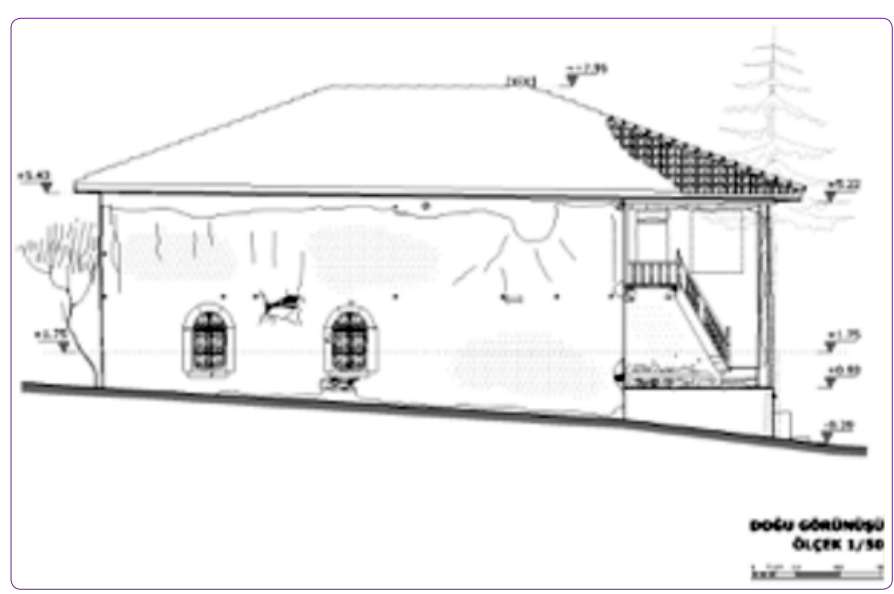

Şekil 12. Doğu Görünüşü (Çizim: Aslıhan Ece Paköz).

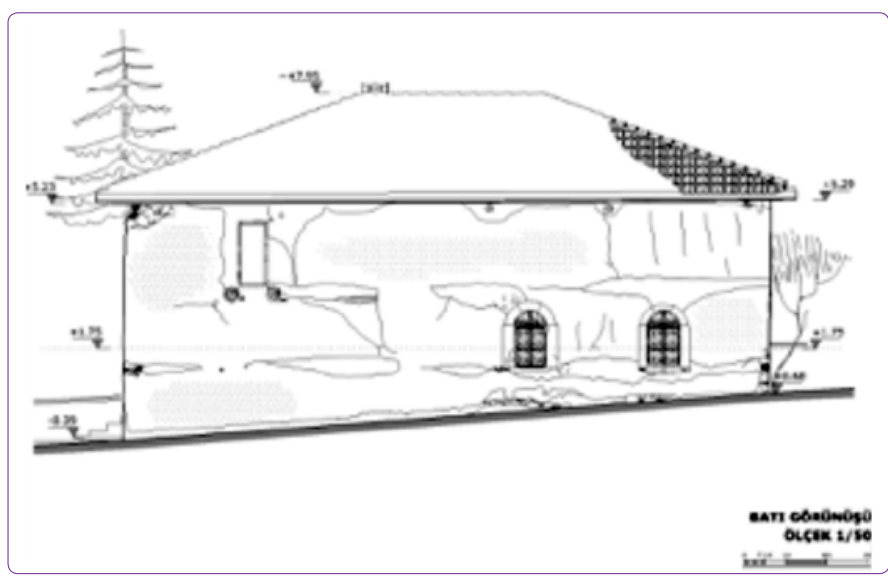

Şekil 13. Batı Görünüşü (Çizim: Aslıhan Ece Paköz).

larda ve dışarıda son cemaat yeri duvarlarında sıva üzerine boya ve kalem işi bezeme yapılmıştır. Diğer dış cephelerde boyasız sıvalı yüzey görülmektedir. Dış cephede çatı saçağı altlarında ve pencere kenarlarında sıva dökülmeleri olduğu ve bu kısımlara çimento harçlı sıva ile onarımlar yapıldığı görülmektedir (Şekil 10-13). Cephede sıva onarımları yapılan yerlerde halen derin sıva çatlaklarının mevcut olması; geçmişte yapılan onarımların yetersiz kaldığını ve sorunun yapı sistemi ile ilgili olduğunu göstermektedir. 


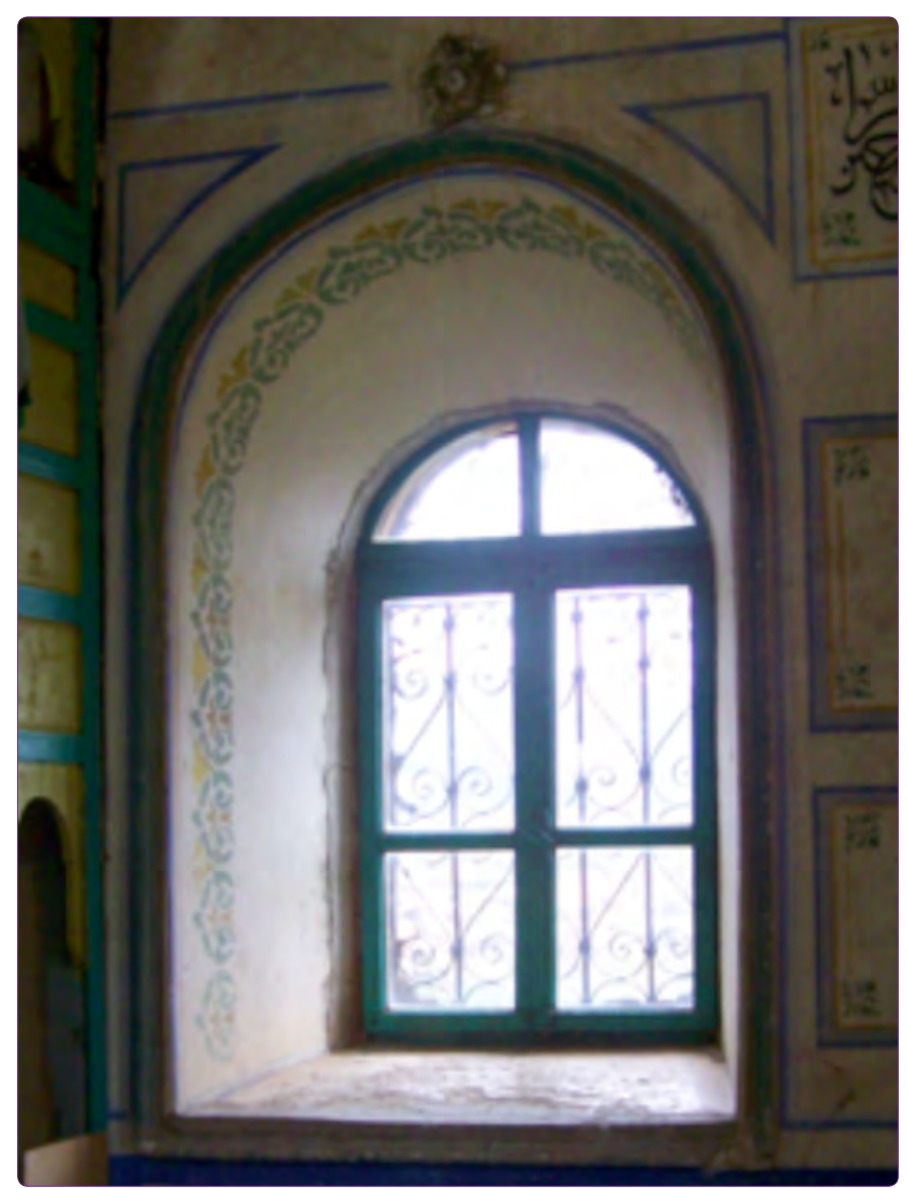

Şekil 14. İç mekândan pencere görünüşü (Fotoğraf: Zeynep Gül Ünal).

Bezemeler: Bademli Camisi'nde bulunan kalem işi duvar bezemelerinin benzerleri, Bademli Köyü'ne yakın yerleşim yerlerindeki daha erken tarihli camilerde de görülmektedir. Örneğin Merkez Recep Bey Camisi (Miladi 1785) ile Merkez Cuma Camisi'nin (Miladi 1709) kalem işlerinin üslubu Bademli Camisi ile benzerdir. Bu camilerin inşa tarihlerinin daha erken döneme ait olmasından dolayı camilerin bezemelerinin, yapıların farklı dönemlerinde yapıldığı düşünülmektedir. Bademli Camisi de söz edilen diğer camiler gibi 18. yüzyılda inşa edilmiş ve yapıya kalem işleri daha sonra eklenmiş olabilir.

Yapılan araştrmada Bademli Camisi'nin yapıldığı dönemde Anadolu'nun farklı yerlerinde, duvarlarında manzara resimleri, natürmortlar, cami resimleri, ağaç resimleri olan çok sayıda cami bulunduğu görülmüştür. ${ }^{3}$ Bu camiler 1970'li yıllardan başlayarak akademik araştırmalara konu olmuşlardır. Bademli Camisi'nde manzara resimleri bulunmamakla birlikte; tuğra, hat, cami tasviri, bitkisel bezemeler, natürmort, perde motifi, deniz kabuğu motifi kalem işi bezemeler bulunmaktadır. Mihrabın iki yanında ise dekoratif kolonlar ve bu kolonların taşıdığı dekoratif saçak ile

\footnotetext{
3 "Anadolu'da camilere kadar giren duvar resimleri her bölgeye yayılmıştır" (Arık, 1988; Önsöz).
}

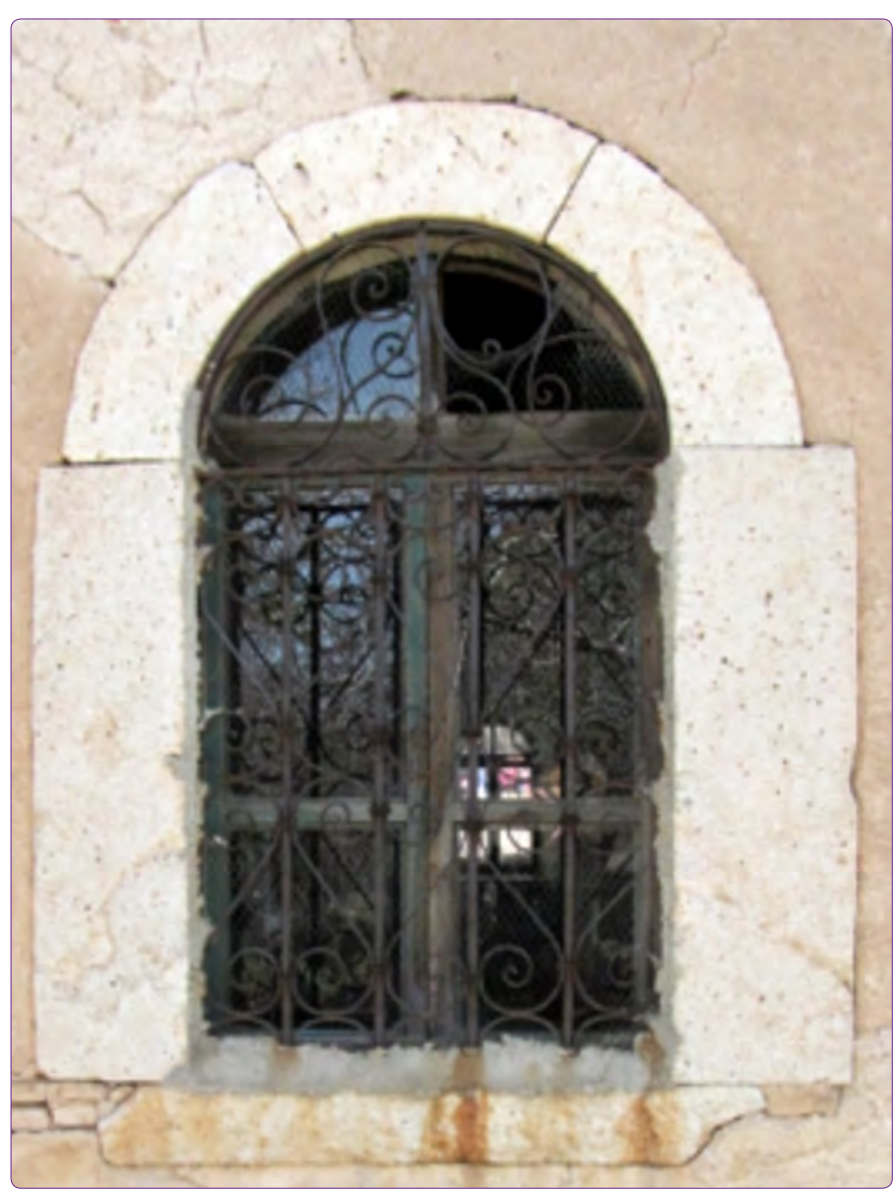

Şekil 15. Dış mekândan pencere görünüşü (Fotoğraf: Zeynep Gül Ünal).

mihrap üst kenarlarında yüksek kabartma gülçeler bulunmaktadır.

Bademli Camisi'ndeki en önemli belgeleri oluşturan kalem işi bezemelerdeki bozulmalar; duvar sıvalarının nemlenmesine bağlı olarak boya tabakasının dökülmesi, çimento içerikli sıva ile bezeme olan duvar üzerinde onarım yapılması, bezemelerin üzerinin boya ile kapatılması, zaman içerisinde mimari unsurlardaki değişikler ya da mimari ekler yapılarak resimlerin kesintiye uğraması olarak sıralanabilir. Bu kalem işi bezemelerin özgün niteliklerini koruması için temizleme, tamamlama gibi müdahaleler yapılmadan korunması gerekmektedir.

\section{Kalem İşleri}

Bademli Camisi'nde bulunan kalem işleri ile ilgili bilgi vermeden önce Osmanlı'da Batılılaşma Dönemi duvar resimlerinden söz etmek gerekir. Böylece hem Bademli Camisi'nde görülen kalem işi örnekleri ortaya çıkaran toplumsal şartlar tahayyül edilebilir hem de duvar resimlerindeki bozulma sorunlarının çözümünde kullanılacak olan dönem resimlerinin özgün hali ile ilgili bilgi edinilebilir.

Minyatürden Batılı resim anlayışına geçiş konusunda ilk kez Rüçhan Arık "Batılılaşma Dönemi Anadolu Tasvir Sa- 
nat"” isimli çalışmasında, ${ }^{4}$ Avrupa üsluplarının Türk mimarisine uygulandığı ilk anıtsal örneklerin, her devirde Türk medeniyetinin "resmi temsilcisi" olan camiler olduğunu, ancak İstanbul camilerinde, figürsüz manzara tasviri de olsa resimli süslere pek cesaret edilmediğini, Anadolu'da ise bu durumun tersine olduğunu söylemiştir. ${ }^{5}$

Bu konuda Renda, 18. yüzyılın sonlarında Anadolu'da yalnız evlerde değil camilerde de resimler bulunduğunu ve resmin camide ya da evde olmasının resimlerin konu ve niteliklerini değiştirmediğini belirtmiştir. ${ }^{6} 18$. yüzyıl, Osmanlı Imparatorluğu'nda yeni bir sanat ortamının oluştuğu ve yeni bir resim anlayışının yerleştiği önemli bir dönemdir. Osmanlı İmparatorluğu'nun ilk kez Batı'ya açıldığı bu dönemde, Avrupa ülkeleriyle kurulan siyasal ve ekonomik ilişkiler, imparatorluğun kültürel ortamını büyük ölçüde etkilemiştir. ${ }^{7}$

19. yüzyılda, Sultan III. Selim'le birlikte, birbirini izleyen yenilikçi reform yanlısı padişahların atılımları ile hızlanan Batılılaşma hareketi, Osmanlı sanatında, mimaride ve tezyîni sanatlarda etkili olmuştur. Kalem işi tezyînât da, Bat sanatının etkili olduğu bu yüzyılda, Barok, Rokoko, Ampir ve eklektik gibi Bat üslûplarının tesirinde kalmış ve yeni bir bezeme anlayışı gelişmiştir. ${ }^{8}$

Tekinalp, 18. yüzyılın ikinci yarısında İstanbul'da görülen duvar resimlerinin kısa sürede imparatorluk sınırları içinde yayıldığını ve Soma, Çanakkale, Gaziantep, Yozgat, Kayseri, Bursa gibi çok farklı merkezde yeni anlayışın kabul gördüğü söylemiştir:" "Gerek başkentte gerek Anadolu ve Rumeli'de tüm sanatçılar, benimsemeye başladıkları yenilikleri manzara resimlerinde denemişlerdir. Hayali olanlar ve olmayanlar diye ikiye ayırabileceğimiz kompozisyonlardan hayali olmayanlar özellikle Mekke-Medine ve İstanbul görünümleridir. Ancak, bu resimler genellikle gözleme dayanan betimlemeler değillerdir. Çoğunlukla ev, konak ve camilerde görülen resimler konumları doğru olmasa da belgeleyici olmaları açısından önem taşırlar".

Özellikle 18. ve 19. yüzyıllarda Anadolu'da inşa edilen tüm yapı gruplarında resimli bezemelerin kullanılması yeni bir türü ve üslûbu göstermektedir. En önemlisi de cami iç mekânlarının bu öğelerle bezenmesidir. Geleneksel bezeme sanatının yerini alan duvar resimlerinin ortaya çıkısı 18. yüzyılın son çeyreğine I. Abdülhamid (1774-1789) ve III. Selim (1789-1807) dönemlerine rastlar. Bu resimler genellikle manzara resmi ve mimari betimlemeler içerir, bir iki istisnai örnek dışında figür bu resimlerde kullanılmaz. Duvarlardaki bu resimler bir nevi tablo asmak gibi yeni bir maddi ve manevi simgeler dizgesinin var edilmesi anlamına gelmektedir. ${ }^{10}$

Diğer yandan belirtmek gerekir ki; ibadet mekânlarının içinde hat sanatının çeşitli örneklerini görmek her zaman

\footnotetext{
4 Arık, R. (1988) Batılılaşma Dönemi ${ }^{7}$ Renda, 1977, s. 9.

Anadolu Tasvir Sanat, Ankara, Kül- 8 Hatipoğlu, 2007, s. 175.

tür ve Turizm Bakanlığı Yayınları. 9 Tekinalp, 2002, s. 722

5 Arık, 1988, s. 25.

6 Renda, 1977, s. 125
}

mümkündür. ${ }^{11}$ Camilerde gelenek olarak belli yerlere belli yazılar yazılmaktadır. Örneğin, camilerde bir yazı programı ile kaplanmış olan kubbelerin yanı sıra 17. yüzyıldan başlayarak, bir inanç ve seyir nesnesi olarak duvarlara asılan hilyeler ve üzerlerinde Allah, Muhammed ve dört halifenin isimlerinin yazılı olduğu panolar görülmektedir. Osmanlı dünyasından duvara hat levhası asma geleneği kaynaklarda 17. yüzyılda Hafiz Osman tarafindan yapılan hilye düzenlenmesiyle başlatılmaktadır. ${ }^{12}$ Hilyeler ve çok az sayıdaki ahşap tuğra dışında, günümüze ulaşabilmiş levha örneklerinin hiçbiri 17. yüzyıldan geriye gitmemekle beraber bunların sayısında ve türlerinde 18. ve özellikle 19. yüzyılda büyük bir artış gözlenmektedir. ${ }^{13}$

Hatipoğlu, önceleri İstanbul'da saray ve çevresinde etkili olan yeni bezeme anlayışının, Sultan III. Selim döneminde güç kazanan ve devrin siyasi yapılanmasında önemli yeri olan âyanlar vasıtasıyla Anadolu'ya yayıldığını ve bu dönemde, yapıların bezemesindeki en büyük yeniliğin duvar resimlerinin ortaya çıkışı olduğunu söylemiş ve 19. yüzyılda Osmanlı'da bezeme anlayışındaki bütün gelişmelerin, Avrupa sanatının felsefesinden beslenmeyen, yüzeysel taklitlerden ibaret kaldığını ve daha da önemlisi, bütün bu çabaların neticesinde, Türk tezyinât açısından kayda değer bir şey üretilemediğini belirtmiştir. ${ }^{14}$

Renda, bu dönemde yapıların duvarlarında görülen manzaralı panolar için kullanılan "duvar resmi" terimini şöyle açıklamaktadır: 15 "Avrupa'da duvar üzerine yapılan resimler genellikle fresko tekniğindedir. Bu teknikte resim yaş sıva üzerine yapılır; oysa Türkiye'de gördüğümüz bu duvar resimleri kuru sıva üzerine yapılmıştı. Zemin ahşap da olsa, üzeri ince bir tabaka alçı ya da tutkallı üstüpeç ile kaplanmış ve bunun üzerine tutkal veya su ile karıştırılmış boyalarla şekiller çizilmiştir. Aslında bu teknik, Osmanlı süsleme sanatında kalem işi denilen nakışların başka bir biçimde uygulanmasıdır".

18. yüzyılın ikinci yarısından itibaren Anadolu'da İstanbul örneklerine paralel duvar resimlerinin görülmesi, uygulanması ve benimsenmesi I. Abdülhamid döneminden sonradır. ${ }^{16}$ Bu dönemde gerek dini gerek sivil mimaride popüler konular i̇stanbul tasvirleridir. Kuru sıva üzerine yapılan duvar resimlerinde cami tasvirleri çoğunlukta olduğu gibi ağaçlar ve bitkisel motifler görmek de mümkündür. Özellikle Bat Anadolu bu konuda zengin örneklerin bulunduğu bir yerdir. ${ }^{17}$ Batı Anadolu'da 19. yüzyılın ilk yarısı itibariyle

\footnotetext{
${ }^{11}$ Bu konuda M. Uğur Derman'ın çalışmalarına bakılabilir. Örneğin; Derman, M. Uğur (1990) Türk Hat Sanatının Şaheserleri, Ankara, Kültür Bakanlığı Yayınları.

12 Derman, 1967, s. 8-9. ${ }^{13}$ Okçuoğlu, 2000, s. 17. ${ }^{14}$ Hatipoğlu, 2007, s. 175.

${ }^{15}$ Renda, 1977, s. $78 . \quad{ }^{16}$ Şener, 2011, s. 35.

${ }^{17} \mathrm{Bu}$ konuda şu çalışmalara bakılabilir: Kuyulu, İ. (1994), Bademli Kılcızade Mehmet Ağa Cami (Ödemiş/İzmir), Vakıflar Dergisi, Sayı: 14, s. 147-158; Kuyulu, I. (1998), İzmir ve Çevresindeki Bir Grup Duvar Resminin Düşündürdükleri, II. Uluslararası İzmir Sempozyumu, s. 57-78, İzmir; Çakmak, ş. (2017), Denizli-Çivril Menteş Köyü Camisi, Uluslararası XVIII. Ortaçağ ve Türk dönemi Kazıları ve Sanat Tarihi Araştırmaları Sempozyumu (22-25 Ekim 2014), Bildiriler Kitabı, Efeler Belediyesi Kültür Yayınları, s. 169-178, Aydın; Karaaziz Şener, D. (2014), Soma Hızır Bey (Çarşı) Camii Duvar Resimleri Üzerine Bir Değerlendirme, Turkish Studies, Cilt: 9/10, s. 715-738, Ankara.
} 


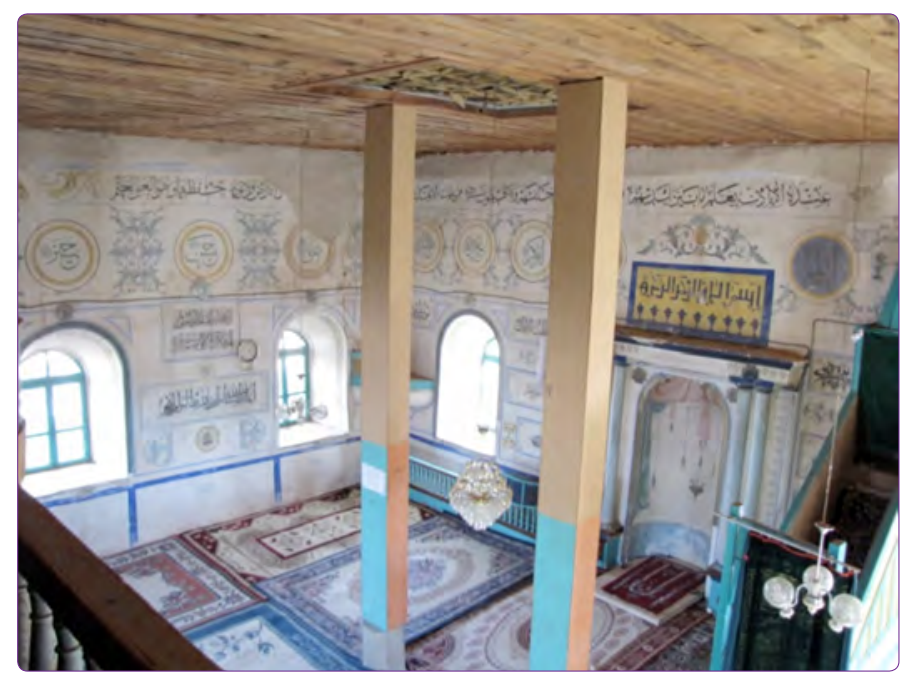

Şekil 16. İç mekândan görünüş (Fotoğraf: Zeynep Gül Ünal).

Afyon, Aydın, Denizli, İzmir, Manisa ve Muğla çevresinde örneklerine rastlanılan ortak bir resim programı ortaya çıkmıştır. ${ }^{18}$ Duvar resimleri başkent İstanbul ve Anadolu'da eş zamanda hızla benimsenir ve yayılmaya başlar. ${ }^{19}$ Ancak Batı bezeme üslubu Osmanlı mimarisinde yerel bir yoruma uğramıştır. Duvar resimlerinde, özellikle dini yapıların duvarlarında yaygın olarak Mekke-Medine, cami ve türbe betimlemeleri bulunur. Bu konuların seçiminde elbette İslam dünyasının dinsel-düşünsel alt yapısı belirleyici olmaktadır. Örneğin, çoğunlukla Sultan Ahmed Camisi (kroki anlayışı ile karşımıza çıkar) betimlenir. ${ }^{20}$ Duvar resimleri genel anlamda gerçekliğin kendisini değil, resmedilmesi hedeflenenin imgesini ele alır. ${ }^{21}$ istanbul imgesi yaratmanın temel araçları ise simge-yapıtların kullanılmasıdır. Bu bağlamda Sultan Ahmed Camisi, halifeliğin ve İslâmiyet'in merkezini simgelemektedir. ${ }^{22}$ Doğal olarak en çok tercih edilen yapıdır. Alt minaresi ile İstanbul camileri içinde tek örnek olan Sultan Ahmed Camisi, duvar resimlerinde şematik anlatmında kolayca tanınabilir olmaktadır. ${ }^{23}$

Araştrılan kaynaklarda Bademli Camisi'nin duvarlarında görülen bezemelerin döneminde Anadolu'da yapılan birçok cami ile benzer özellikler taşıdığı anlaşıımaktadır. Ancak bu çalışmalar içerisinde Dinar'daki Bademli Camisi'ne rastlanılmamıştır.

Yapının iç ve dış duvarlarında çok sayıda bezeme vardır. Biçimsel bezemeler iki gruba ayrılabilir. Bunlardan birinci grubu yazı programı oluştururken, ikinci grubu bitkisel bezemeler ve resimli panolar oluşturmaktadır. Ancak bezemelerin iş̧̧ilik kalitesi göz önüne alındığında caminin biri yapım aşamasında olmak üzere, diğeri ise tespit edilemeyen bir dönemde olmak üzere iki dönemde bezeme programına tabi tutulduğu söylenebilir.

\footnotetext{
${ }^{18}$ Şener, 2011, s. $38 \quad{ }^{19}$ Şener, 2011, s. $25 . \quad{ }^{20}$ Okçuoğlu, 2000, s. 39.

${ }^{21}$ Okçuoğlu, 2000, s. $39 . \quad{ }^{22}$ Okçuoğlu, 2000, s. $41 .{ }^{23}$ Okçuoğlu, 2000, s. 41.
}

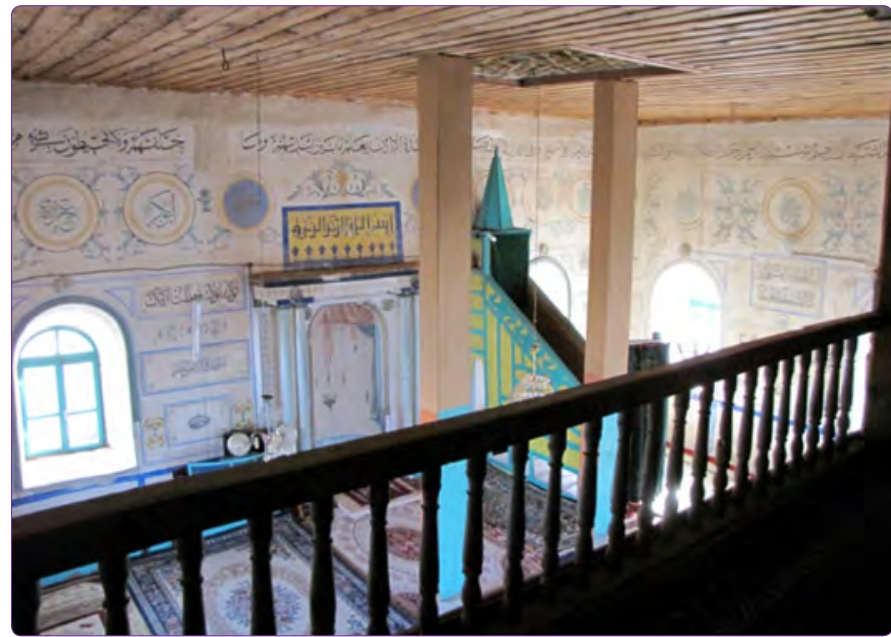

Şekil 17. İç mekândan görünüş (Fotoğraf: Zeynep Gül Ünal).

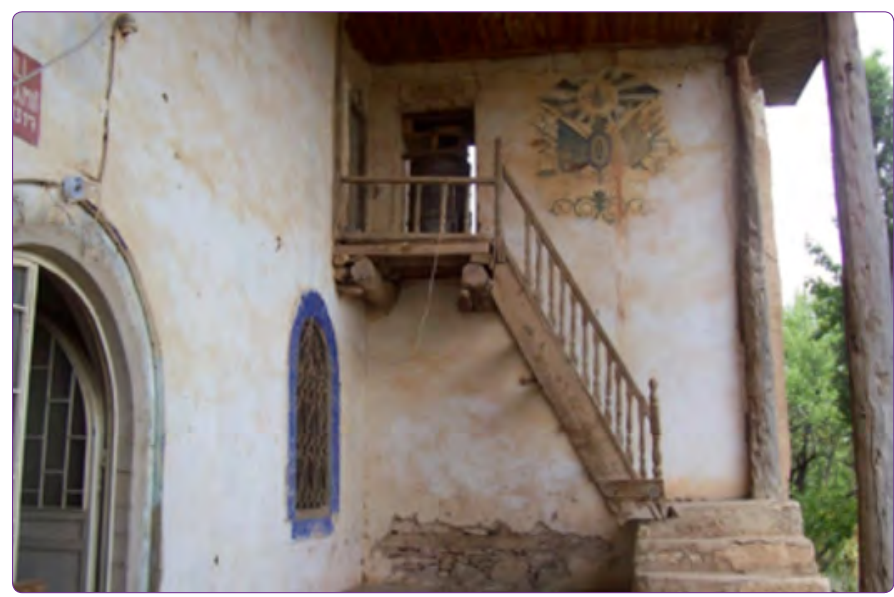

Şekil 18. Son cemaat yerinin batı duvarındaki kalem işi (Fotoğraf: Zeynep Gül Ünal).

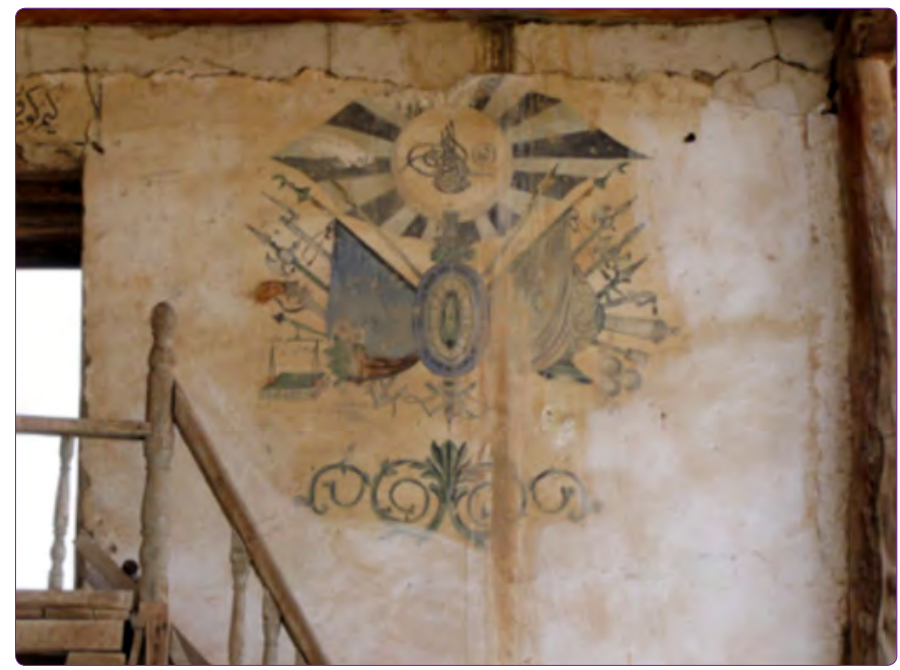

Şekil 19. Son cemaat yerinin batı duvarındaki kalem işi (Fotoğraf: Zeynep Gül Ünal).

Bademli Camisi'nde iç mekânın dört duvarında ve dışarıda son cemaat yeri duvarında kalem işleri bulunmaktadır (Şekil 16-19). íç mekân duvarlarında kalem işi tekniği ile 
yapılan çok sayıda hat, cami ve tabiat tasvirleri vardır. Son cemaat yerinin batı duvarı üzerinde yer alan 19. yüzyılın ikinci yarısında ortaya çıkan, inşa ya da tamir edilen her resmî yapının cephesinde yer alan kısmen boyayla kapatlan kalem işi Osmanlı arması dikkat çekicidir (Şekil 18-19). Osmanlı İmparatorluğu'nu her yerde temsil eden bu armalar, son şeklini II. Abdülhamid döneminde almıştır.

Bu süslemelerin dışında camide pencerelerin çevresinde alçı silmeler ve kemer üstlerinde aynı şekilde kabartma gülçeler (Şekil 20); tavanda, minberde ve vaaz kürsüsünde ahşap bezemeler (Şekil 21-23); giriş kapısının kemer taşlarında kabartma süslemeler bulunmaktadır (Şekil 24). Son cemaat yerinin kuzey duvarında kalem işlerinin üzeri boyandığından, motiflerin sadece izleri görülebilmektedir (Şekil 25).

Doğu Duvarı: Cami iç mekânı doğu duvarında, büyük ölçekte yapılmış kalem işi çifte vav ve iç köşelerinin her birinde sarı renkli Barok bitkisel bezemeler bulunmaktadır (Şekil 26, 27). Doğu duvarında bulunan iki pencere-

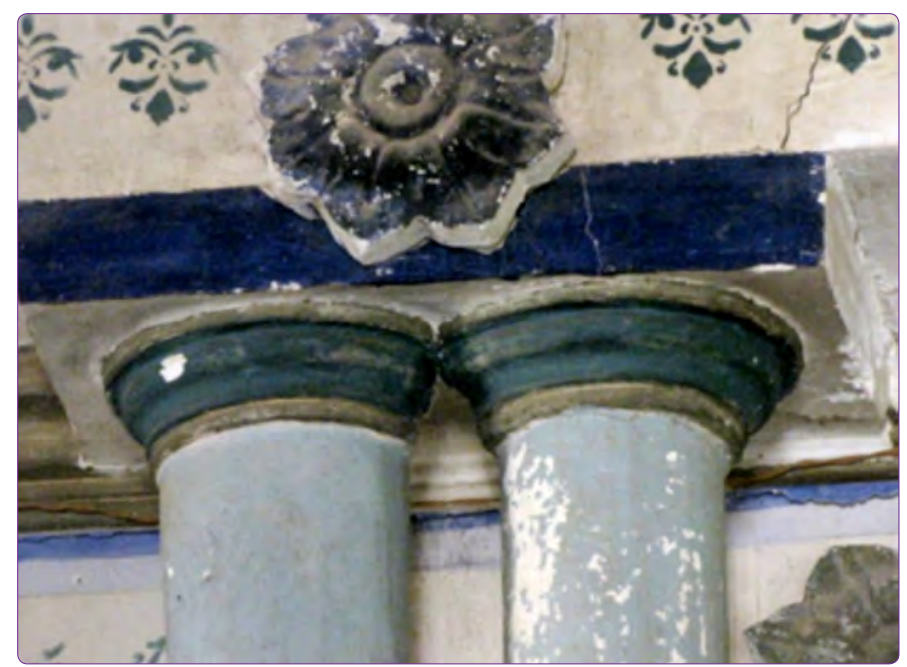

Şekil 20. Mihraptaki kabartma gülçe (Fotoğraf: Zeynep Gül Ünal).

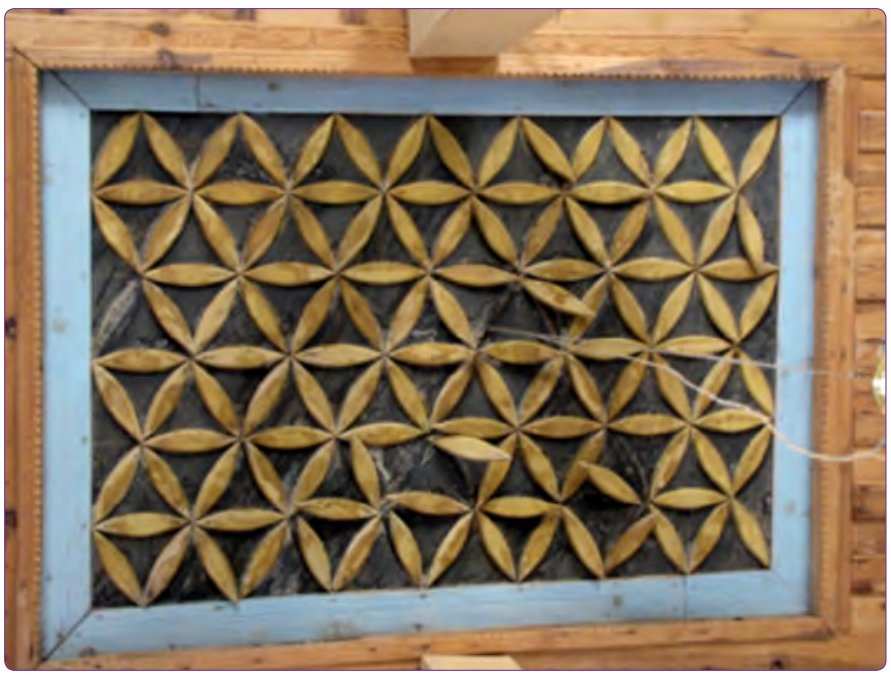

Şekil 21. Tavandaki ahşap bezeme (Fotoğraf: Zeynep Gül Ünal). nin üst kısmında kalem işi madalyon şeklindeki panoların içerisinde sülüs yazı ile sırasıyla; "Talha radıyallahu anh",

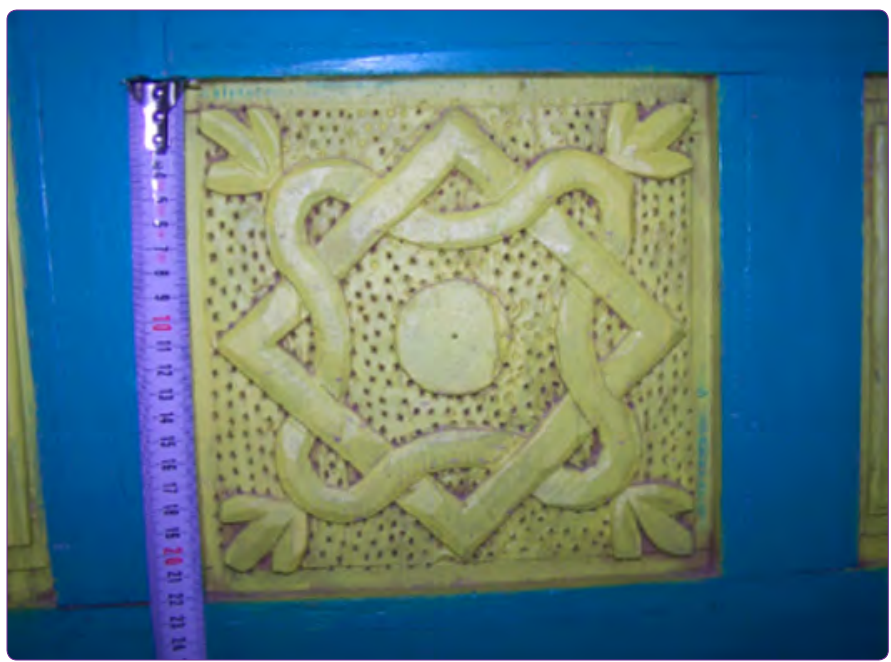

Şekil 22. Minberdeki ahşap bezeme (Fotoğraf: Zeynep Gül Ünal).

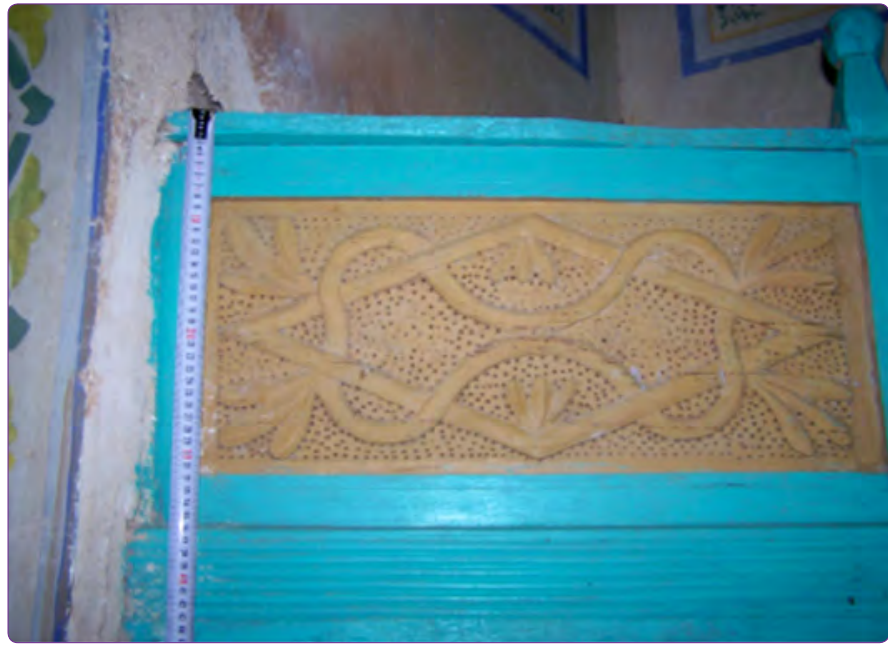

Şekil 23. Vaaz kürsüsündeki ahşap bezeme (Fotoğraf: Zeynep Gül Ünal).

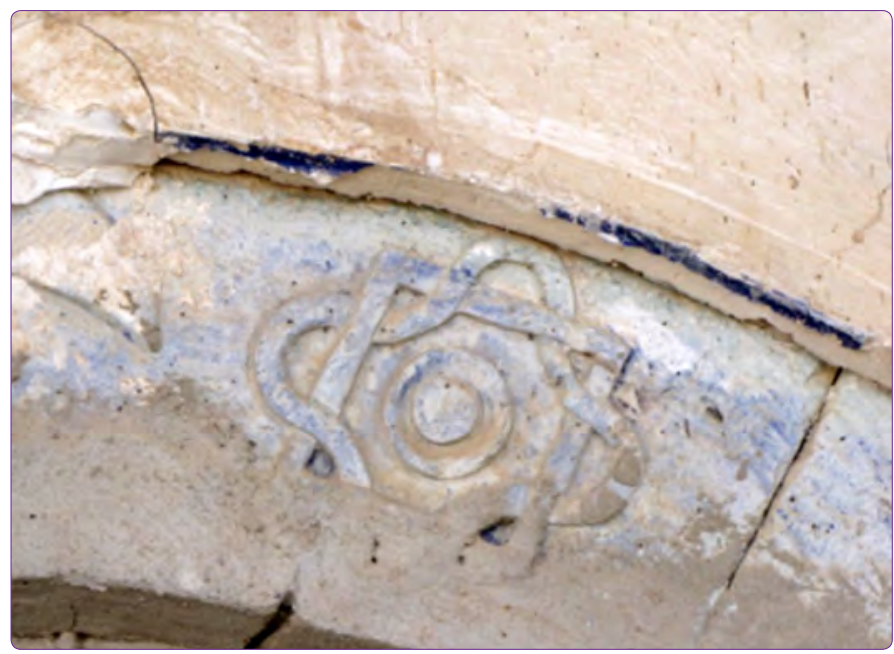

Şekil 24. Giriş kapısı kemer taşındaki kabartma süsleme (Fotoğraf: Zeynep Gül Ünal). 


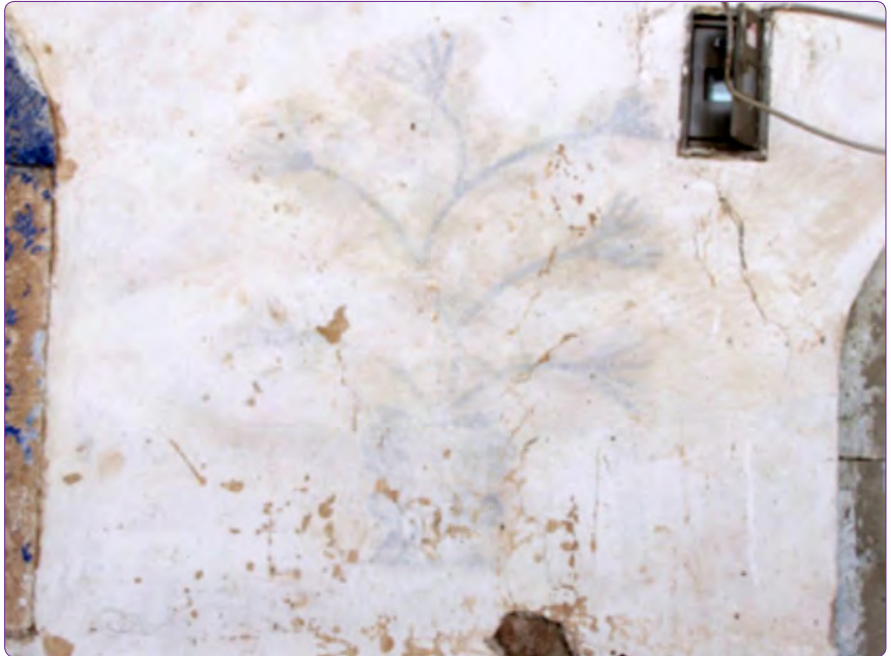

Şekil 25. Son cemaat yerinin kuzey duvarında üzeri boyanmış kalem işi (Fotoğraf: Zeynep Gül Ünal).

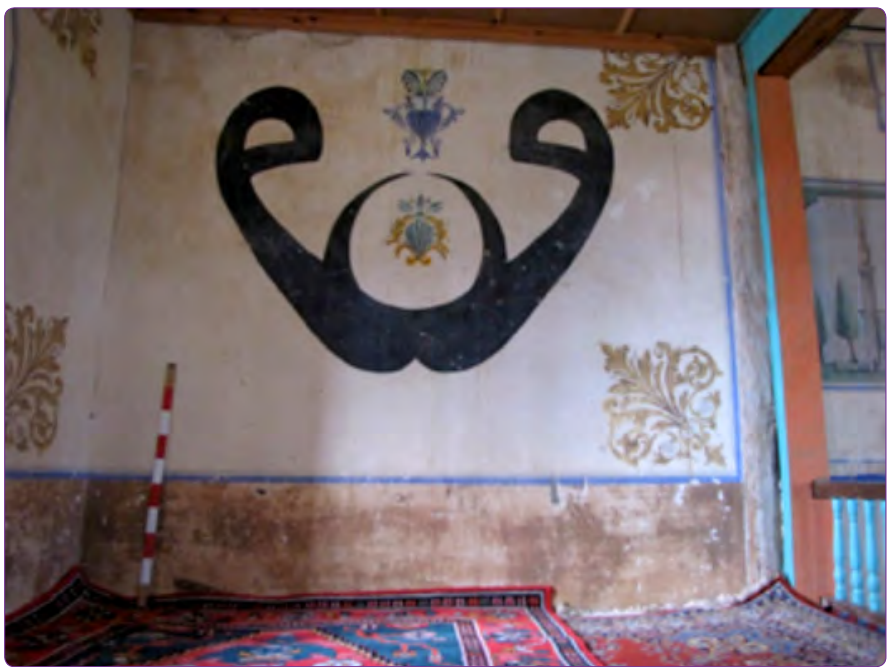

Şekil 26. Cami iç mekânı doğu duvarındaki kalem işi çifte vav (Fotoğraf: Zeynep Gül Ünal).

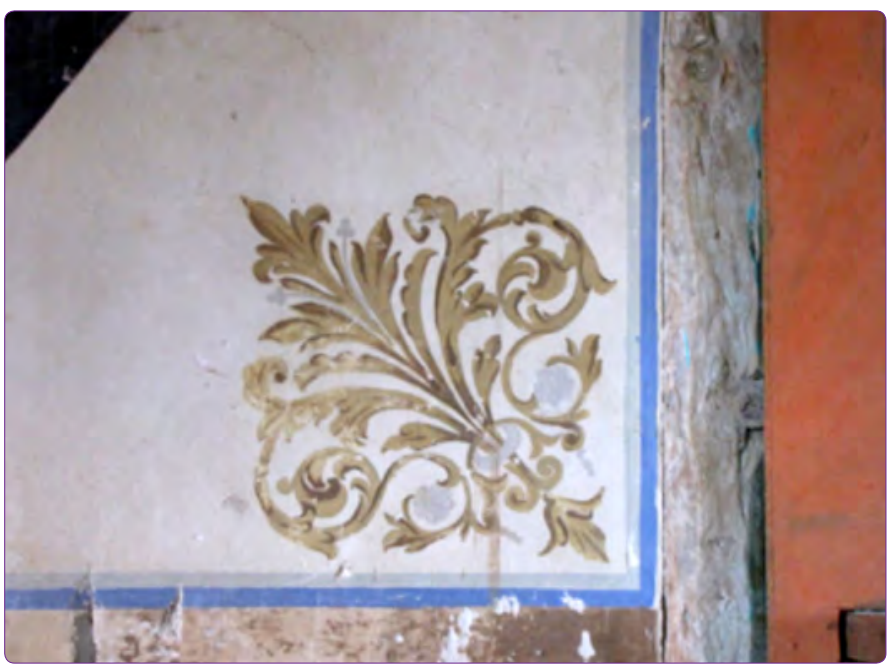

Şekil 27. Cami iç mekânı doğu duvarındaki barok bitkisel bezemeler (Fotoğraf: Zeynep Gül Ünal).
"Hüseyin radıyallahu anh", "Hasan radıyallahu anh", "Ali Kerremellâhu veche, radıyallahu anh" isimleri yeşil renkle yazılmıştır (Şekil 28). En üst kısımda bulunan yazı kuşağında Bakara Sûresi'nin 255. ayetinin son kısmı yazıııdır;

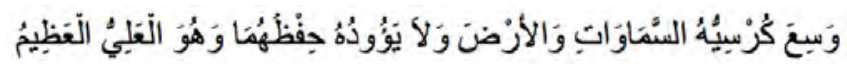

"Vesi'a kursiyyuhu-ssemâvâti vel-ard(a)(s) velâ yeûduhu hifzuhumâ vehuve-l'aliyyu-l'azîm(u)" (Hükümranlığı gökleri ve yeri kaplamıştır, onların gözetilmesi, O'na ağır gelmez; $O$ yücedir, büyüktür). ${ }^{24}$

Yazı kuşağı bitkisel motifle son bulur. Bu kısım pencerelerin üstünden başlayan mavi renkli bir çerçeveyle alt kısımdan ayrılır; resim ve yazı panolarının bulunduğu kısım başlar. Doğu duvarında girişe göre ilk pencerenin kuzeyinde bulunan panoda Ashab-ı Kehf'in isimleri gemi biçiminde istiflenerek yazıımıştır (Şekil 29), altında bulunan pano-

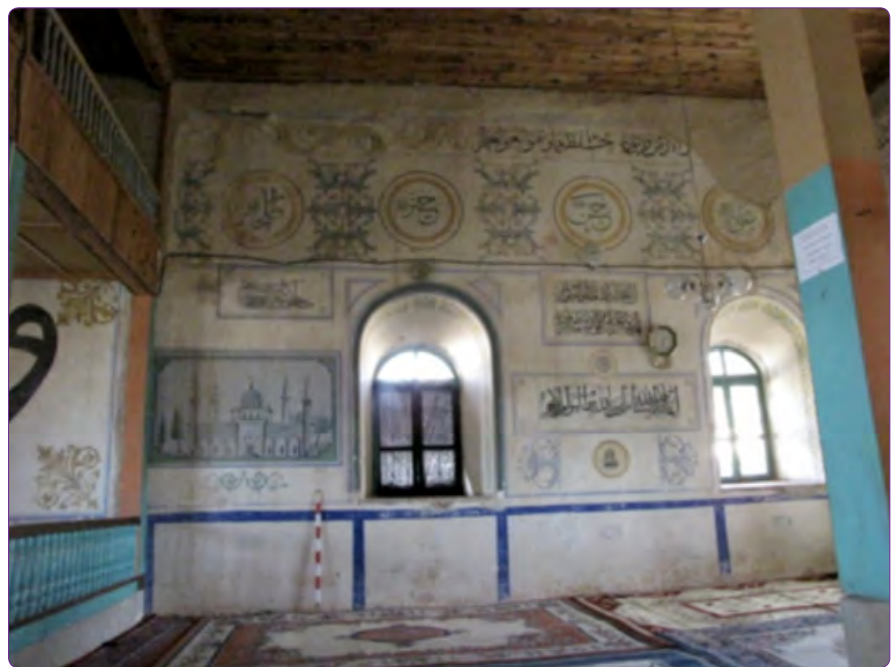

Şekil 28. Doğu duvarı (Fotoğraf: Zeynep Gül Ünal).

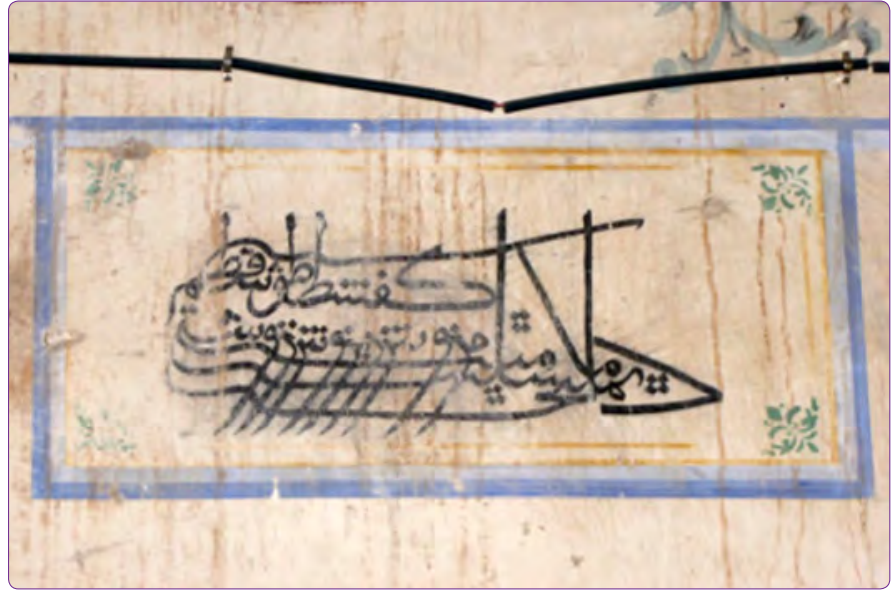

Şekil 29. Doğu duvarında, gemi biçiminde istiflenerek yazılmış Ashab-ı Kehf'in isimleri (Fotoğraf: Zeynep Gül Ünal).

\footnotetext{
24 Tercüme: Kur'ân-ı Kerîm ve Türkçe Anlamı (Meâl) (1985), Ankara, Diyanet İşleri Başkanlığı Yayınları, s. 41.
} 


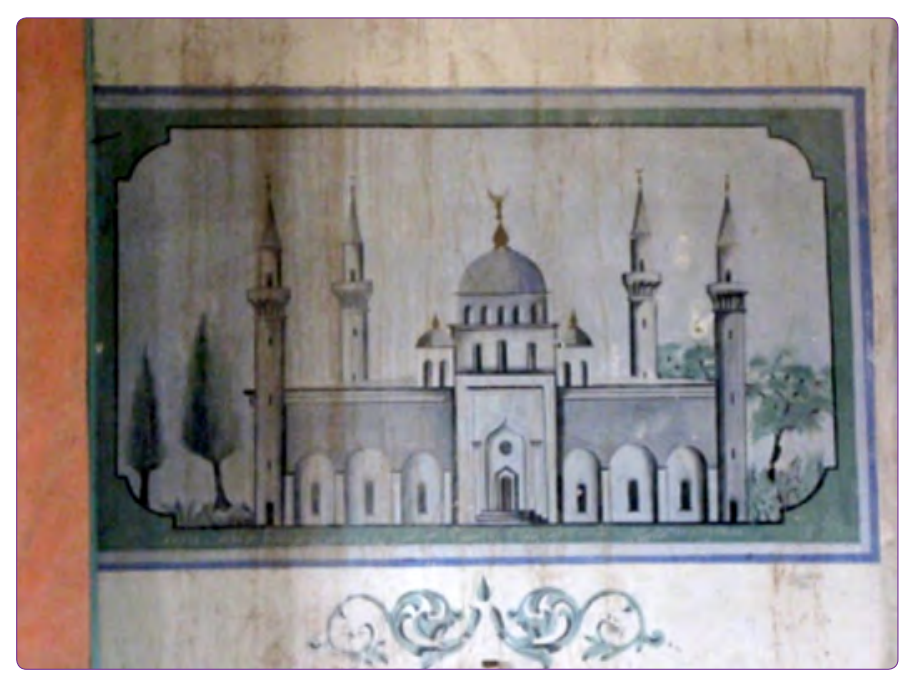

Şekil 30. Doğu duvarındaki dört minareli cami resmi (Fotoğraf: Zeynep Gül Ünal).

da ise tahminimizce yapının ilk bezeme dönemine ait, dört minareli bir cami resmi bulunmaktadır (Şekil 30), bu kısmın altında da yine Barok bir bitkisel bezeme bulunur.

Doğu duvarındaki iki pencerenin arasında bulunan tek çerçeveli hat panolarında ise sırasıyla şunlar yazılıdır: Zumer Sûresi 53. ayetin ikinci kısmı;

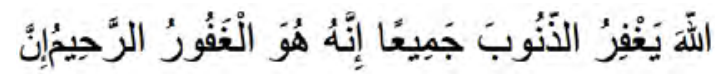

"Innallâhe yagfiruz zunûbe cemîâ (cemîan), innehu huvel gafûrur rahîm (rahîmu)" ile başlayıp ikinci satır ayetin başlangıç kısmı ile sonlanır;

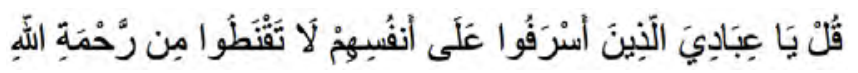

"Kul yâ ıbâdiyellezîne esrefûalâ enfusihim lâ taknetû min rahmetillâhi"; 53. Ayet Kur'an-ı Kerîm'de şu şekildedir:

"Kul yâ ıbâdiyellezîne esrefûalâ enfusihim lâ taknetû min rahmetillâhi, innallâhe yagfiruz zunûbe cemîâ (cemîan), innehu huvel gafûrur rahîm (rahîmu)" (Ey kendilerine kötülük edip aşırı giden kullarım! Allah'ın rahmetinden umudunuzu kesmeyin. Doğrusu Allah, günahların hepsini bağışlar. Çünkü O, bağışlayandır, merhametlidir). ${ }^{25}$

Yazının hemen altındaki madalyonun içinde sarı renkle istif olarak besmele, "Bismillahirrahmanirrahim" bulunmaktadır, Besmele'nin altındaki yazı panosunda ise Tevbe Sûresi 18. ayetin başlangıç kısmı yazılıdır;

$$
\text { إِنَّمَا يَعْمُرُ مَسَاجِدَ اللّهِ مَنْ آََنَ بِالَّهِ وَالْيَوْمِ الآخِرِ }
$$

“innemâ ya'muru mesâcidallâhi men âmene billâhi velyevmilâhıri" (Allah'ın mescidlerini sâdece, Allah'a ve âhiret gününe inanan, namaz kılan, zekât veren ve ancak Allah'tan korkan kimseler onarır). ${ }^{26}$

\footnotetext{
${ }^{25}$ Kur'ân-ı Kerîm ve Türkçe Anlamı ${ }^{26}$ Kur'ân-ı Kerîm ve Türkçe Anlamı (Meâl), 1985, s. 463.

(Meâl), 1985, s. 188.
}

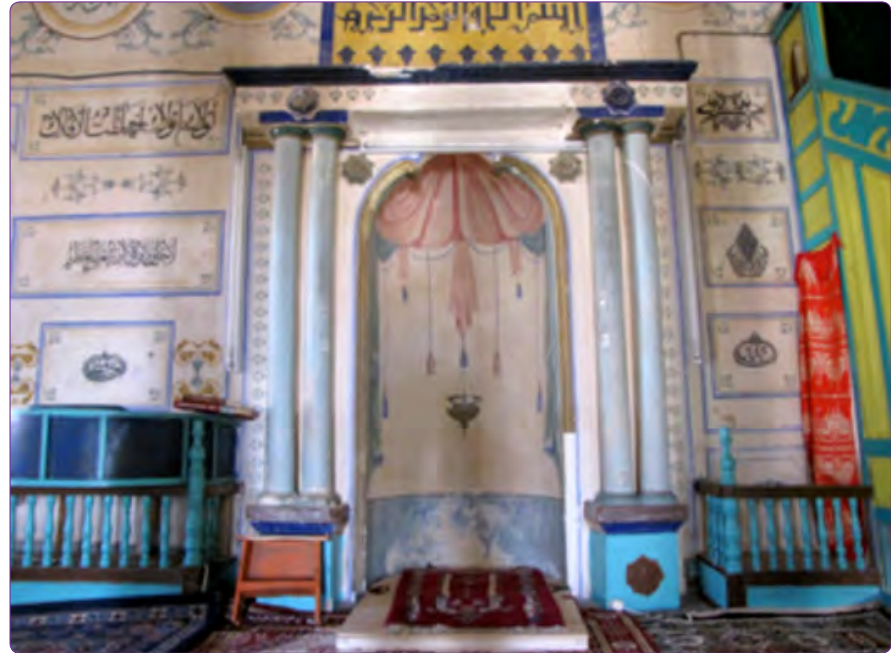

Şekil 31. Güney duvarındaki mihrapta perde motifi (Fotoğraf: Zeynep Gül Ünal).

Bunun altnda ise her iki tarafi bitkisel bezeme ile donanmış olan madalyonda müsennâ "El-hamdüllilah" yazmaktadır. Üzerinde kalem işi bitkisel motifler olan vaaz kürsüsünün üst tarafinda bulunan panoda sülüs "Sadakallahü’lâzim" yazmaktadır. Simetriğinde ise "Nûrunalânûr" yazılı bir pano bulunmaktadır.

Güney Duvarı: Cami iç mekânı güney duvarındaki mihrapta perde motifi bulunmaktadır (Şekil 31). Perdeden aşağıya kordonlar ve motifin ortasında zincire asılı kandil sarkmaktadır. Tali, resimlerde kullanılan perdenin sembolik olarak iki âlemi ayıran bir motif olduğunu belirtmektedir. ${ }^{27}$ İslam'da mihrap Allah'a dönülen, kişinin nefis ve şeytanla mücadele ettiği bir yer olarak tanımlanır. Mihraba dönen kişi dini olarak istikamette olduğundan üzerine Allah'ın nurunun yansıması temsili olarak kandil motifi ile sağlanır. ${ }^{28}$ Araştırılan kaynaklarda bu dönem yapılarının birçoğunda mihrapta bu motifin kullanıldığı görülmüştür.

Caminin güney duvarında bulunan mihrabın üst kısmında lacivert çerçeveli panoda kufî yazısıyla besmele ve onun üst kısmında Barok bir bitkisel bezeme bulunmaktadır. Ancak besmelenin bulunduğu panoda kullanılan renkler ve iş̧̧ilik göz önüne alındığında bu panonun sonraki bir dönemde eklendiği söylenebilir (Şekil 32). Besmelenin bat tarafinda bulunan mavi zeminli madalyonun içinde sülüs hatt ile "Allah", hemen yanındaki istifte ise "Cellecelaluhu" (O'nun şanı ne yücedir) ibaresi yazmaktadır. İstifin kenarına sarı renkle hat çekilmiş ve bunun dışına kahverengi ikinci bir çerçeve eklenmiştir. Aynı şekilde doğu tarafta ise "Muhammed", yazının bitimindeki istifte "Resulullah" yazmaktadır. Bat taraftaki "Allah" yazısının devamındaki aynı biçimdeki madalyonların zeminleri duvarla aynı renkte bırakılıp sırasıyla şu isimler yeşil renkle sülüs istif olarak yazılmıştr: "Sa'd bin Ebî Vakkas", "Said bin Zeyd", "Abdurrahman bin Avf".

\footnotetext{
${ }^{27}$ Tali, 2013, s. $505 . \quad 28$ Yelen, 2017, s. 474.
} 


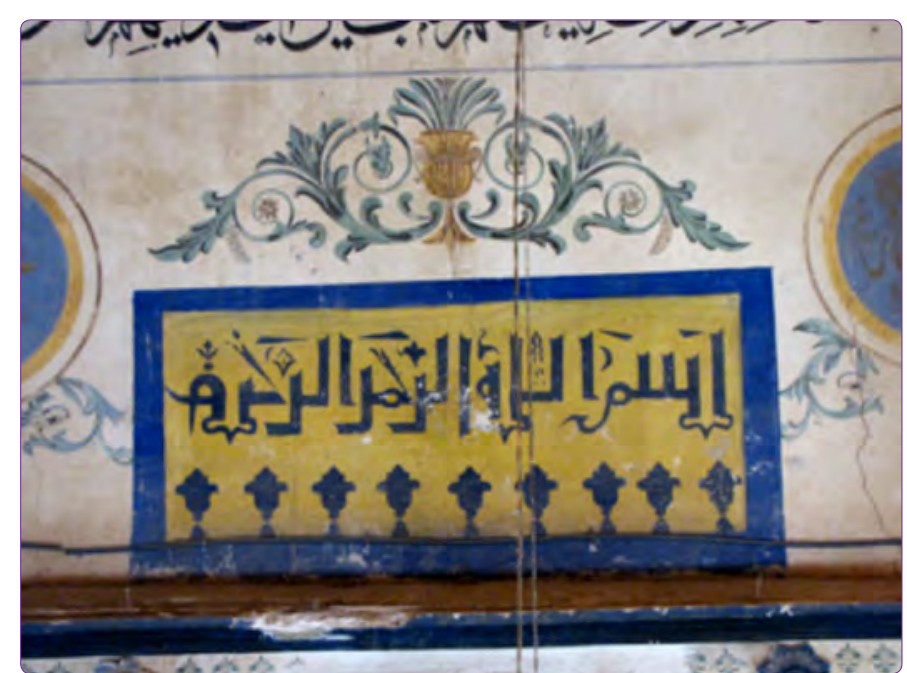

Şekil 32. Mihrabın üst kısmında, kufî yazısıyla yazıımış besmele (Fotoğraf: Zeynep Gül Ünal).

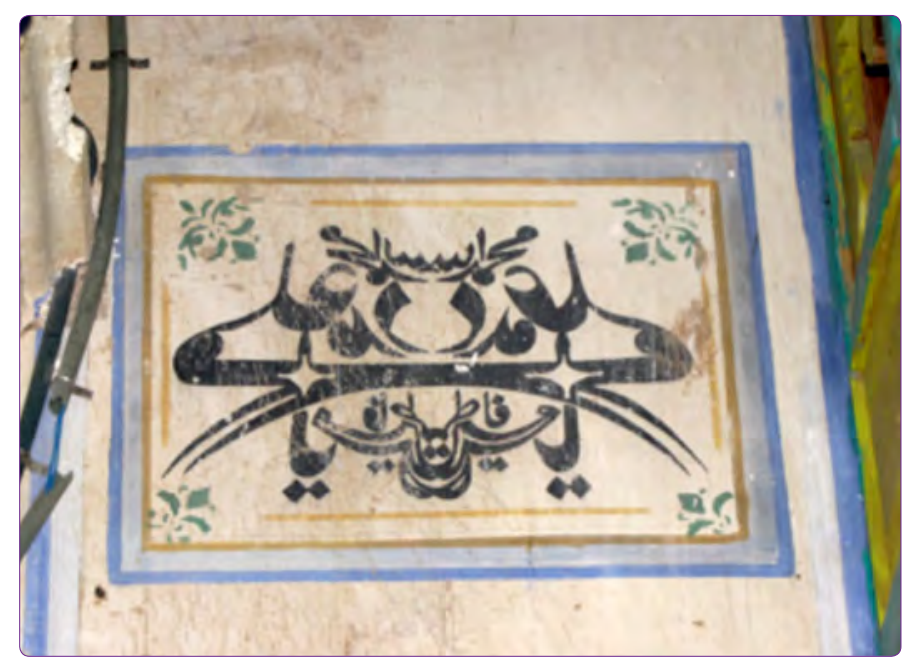

Şekil 33. Mihrabın batı tarafındaki "Yâ Ali" yazısı (Fotoğraf: Zeynep Gül Ünal).

Mihrabın doğu tarafinda bulunan "Muhammed" yazısından sonra aynı şekilde "Ebubekir", "Ömer" ve "Osman" isimleri sülüs hattyla yazılmıştır. Burada isimleri yazılan olan sahabelerin hepsi aşere-i mübeşşere olarak bilinen yani kendilerine cennetin müjdelendiği on sahabeden altısıdır. Mihrabın bat tarafinda yer alan mavi renkli kalem işi panolar içerisinde sülüs müsennâlar ve Barok bezemeler bulunur: "Yâ Ali" yazısından sonra (Şekil 33), yerleştirilen Barok bezemenin ardından Fetih Sûresi'nin 1. ayeti müsennâ olarak;

\section{إِنَّا فَتَحْنَا لَكَكَ فَتْحًا مُبِينًا}

"İnnâ fetehnâ leke fethan mübînen" (Ey Muhammed biz sana apaçık bir fetih ihsan ettik") ve bunun yanında da "Maşaallah" ibaresi bulunur (Şekil 34). Minberin batısında yer alan pencerenin bat duvarı ile birleşiminde üst taraftaki panoda Yusuf Sûresi'nin 64. ayeti;

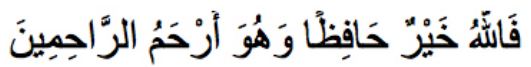

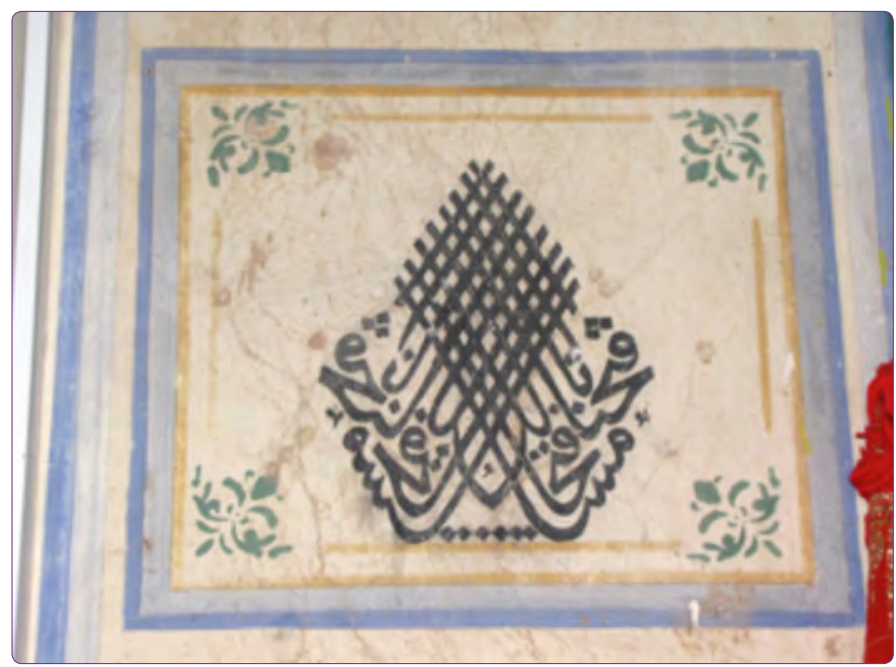

Şekil 34. Mihrabın batı tarafındaki Fetih Sûresi'nin 1. Ayeti (Fotoğraf: Zeynep Gül Ünal).

"Fallâhu hayrun hâfizâ (hâfizen) ve huve erhamur râhimîn (râhimîne)" (Allah en iyi koruyandır, O merhametlilerin merhametlisidir), ${ }^{29}$ hemen altında, Hud Sûresi'nin 88. ayetinin son kısmı;

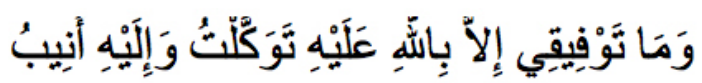

"Ve mâtevfikî illâ billâh (billâhi), aleyhi tevekkeltu ve ileyhi unîb (unîbu)" (Başarım ancak Allah'tandır, O'na güvendim; O'na yöneliyorum), ${ }^{30}$ ve "El-amânmaa el-imân" (iman ile güvence) yazmaktadır. Diğer dört sahabenin ismi bat duvarında bulunan aynı biçimdeki dairesel panolarının içine yazılmıştır.

Bat Duvarı: Cami iç mekânı batı duvarında güney tarafta yazılan ilk isim "Ebu Ubeyde bin Cerrah" olup sırasıyla "Zübeyr bin Avvam", "Abbas" ve "Amr" isimleri bulunmaktadır. Yalnız "Amr" isminin üst kısmı yapılan bir tamir neticesinde sıvayla kapanmıştır. Daire formundaki bu pano yazılarının aralarında Barok bitkisel bezemeler vardır. Bat duvarında bulunan bezemelerin bir kısmı ise yapıya sonradan eklenen kadınlar mahfili taşıyıcı elemanlarının altında kalmıştr. Kadınlar mahfili kısmındaki dikdörtgen pano içerisinde sülüs ile yazılmış "Bilal-i Habeşi" ismi bulunur. Diğer bitkisel bezemenin ise sonradan yapılan tamir nedeniyle günümüze sadece bir kısmı ulaşmıştr. Alt katta yerden yükseltilmiş bölümden yukarıya çıkışı sağlayan merdiven nedeniyle de kalem işi olan çifte vav'ın bir kısmı görülememektedir.

Bat duvarının tavan ile birleştiği, "Amr" isminin bulunduğu madalyonun üst kısmında bitkisel motiften sonra "Euzu besmele" ve ardından "Ayetelkürsi" başlamakta ve yazı kuşağı güney duvarı boyunca, ardından da doğu duva-

\footnotetext{
${ }^{29}$ Kur'ân-ı Kerîm ve Türkçe Anlamı ${ }^{30}$ Kur'ân-ı Kerîm ve Türkçe Anlamı (Meâl), 1985, s. 242.
} 


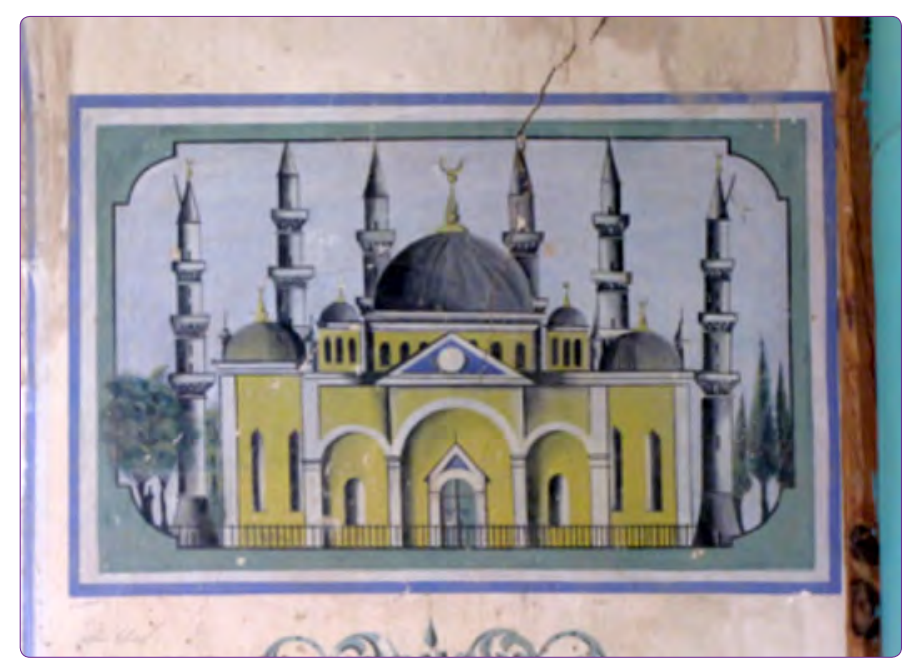

Şekil 35. Batı duvarındaki altı minareli cami resmi (Fotoğraf: Zeynep Gül Ünal).

rına devam ederek burada sonlanmaktadır. Batı duvarında bulunan bir başka yazıda ise Arapça;

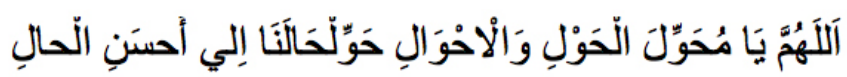

“Yâ muhavvile'I-havli ve'I-ahvâl havvi'|-hâlenâ ilâ ahseni'|hâl" (Ey hâlleri iyiden kötüye, kötüden iyiye çeviren [Allah'ım] bizi en güzel hâle çevir) yazılıdır. Bu yazının hemen altında alt minareli cami yani Sultan Ahmed Camisi resmi bulunan bir pano bulunmaktadır (Şekil 35). Duvardaki iki pencere arasına yerleştirilmiş mavi çerçeveli panonun içerisinde iki satırlık sülüs yazıda ise Azhap Sûresi'nin 56. ayeti yazılıdır;

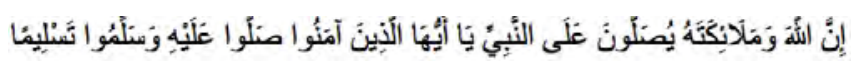

“innallâhe ve melâiketehu yusallûne alen nebiyyi, yâ eyyuhâllezîne âmenû sallû aleyhi ve sellimû teslîmâ (teslîmen)" (Şüphesiz Allah ve melekleri Peygamber Muhammed'i överler; ey inananlar! Siz de Onu övün, Ona salât ve selâm getirin). ${ }^{31} \mathrm{Bu}$ yazının altında yine sülüs istifiyle kalem işi sarı çerçeveli pano içinde "Bismillahirrahmanirrahim" yazılıdır. Bu yazı alttaki çerçeve ile birleşmektedir. Açık mavi çerçeve içerisinde köşelerinde bitki motifi bulunan sarı bir iç çerçevenin içinde Nisâ Sûresi'nin 103. ayetinin son kısmı;

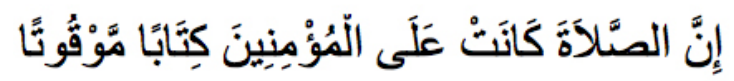

“inne's-salâte kânet aşe'l-mü'mîne kitâben mevkuten” yazılıdır (Namaz şüphesiz, inananlara belirli vakitlerde farz kılınmıştır). ${ }^{32}$ Bu yazının altında ise müsennâ "Elhamdüllillah" bulunmaktadır. Pencerenin sol tarafinda üst kısımda bulunan kalem işi çerçeveli panonun içinde kısmen okunabilen "Lailaheillallah Muhammeden resulullah" yazııdır.

\footnotetext{
${ }^{31}$ Kur'ân-ı Kerîm ve Türkçe Anlamı ${ }^{32}$ Kur'ân-ı Kerîm ve Türkçe Anlamı (Meâl), 1985, s. 425
}

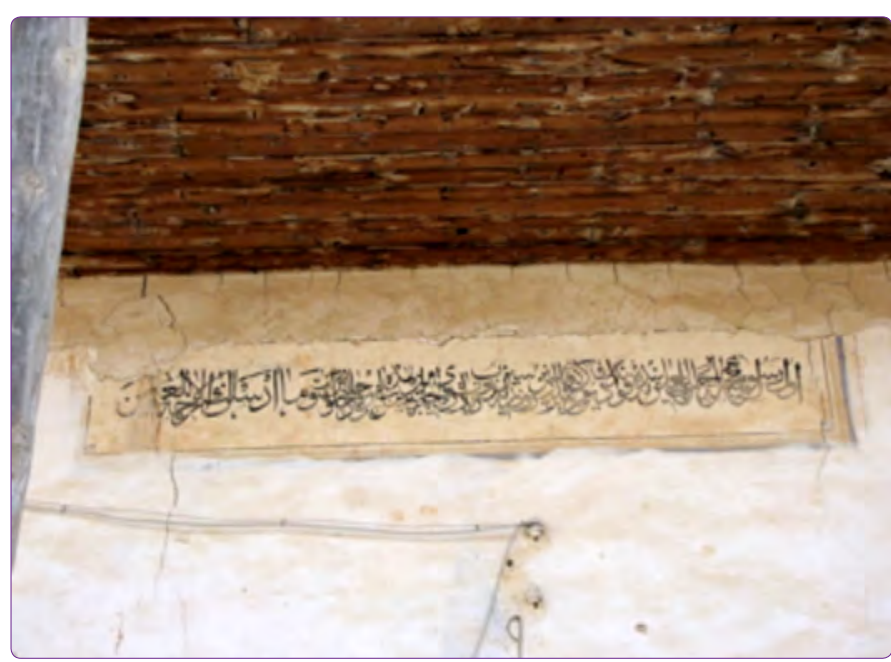

Şekil 36. Kuzey duvarındaki (dış) Enbiya Sûresi'nin 107. Ayeti (Fotoğraf: Zeynep Gül Ünal).

Bunun hemen altında müsenna tasarlanan yazı ise sıva tabakası ile kapatımış olması nedeniyle kısmen okunabilmektedir: "Allah [...]"

Son cemaat yerinin bat tarafinda bulunan duvarda üzeri kısmen boyayla kapatımış Osmanlı arması bulunmaktadır. Bu armanın güney tarafinda kadınlar mahfiline çıkan merdivenin bitimindeki balkon girişinin hemen üzerinde bulunan kalem işi panoda bir kısmı sonradan yapılan tamirler ve bozulmalar nedeniyle kısmen okunabilen "Kim görüp (dir) Maşallah" ibaresi yer almaktadır.

Kuzey duvarı (dış): Bademli Camisi'nin kuzey dış duvarında doğal taş söveli bir giriş kapısı vardır. Özgün kapı kayıptr ve yerinde demir bir kapı bulunmaktadır. Bu duvarda dış cephede kapının üst kısmında üzeri boyayla kapatılmış olmasına rağmen okunabilen $\mathrm{H} .1317$ tarihli kalem işi bir kitabe bulunmaktadır. Bu kitabenin üzerinde yine kalem işiyle çerçeveye alınan yazı panosunda ise "Ol Resûl-i müctebâ hem rahmetenlil âlemin / Bende medfûndur deyu eflâke fahr eyler zemîn / Ravzasın idüp ziyâret didi Cibrîl-i Emîn / Hâzihî Cennâtü Adnin fedhulûhâ hâlidîn / Ve mâ erselnâke illâ rahmeten lil âlemîn" yazmaktadır;

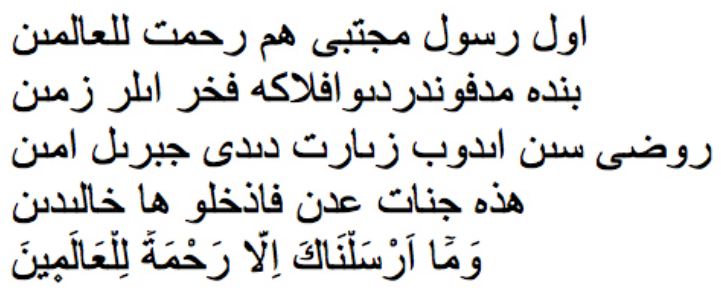

Arapça olan dördüncü mısranın tercümesi şöyledir: "Burası Adn cennetleridir. Buraya ebedî kalacak şekilde girin". Beşinci mısra, Türkçesi "Biz seni ancak âlemlere rahmet olarak gönderdik." 33 olan Enbiya Sûresi'nin 107. ayetiyle sonlanır (Şekil 36).

\footnotetext{
${ }^{33}$ Kur'ân-ı Kerîm ve Türkçe Anlamı (Meâl), 1985, s. 330.
} 


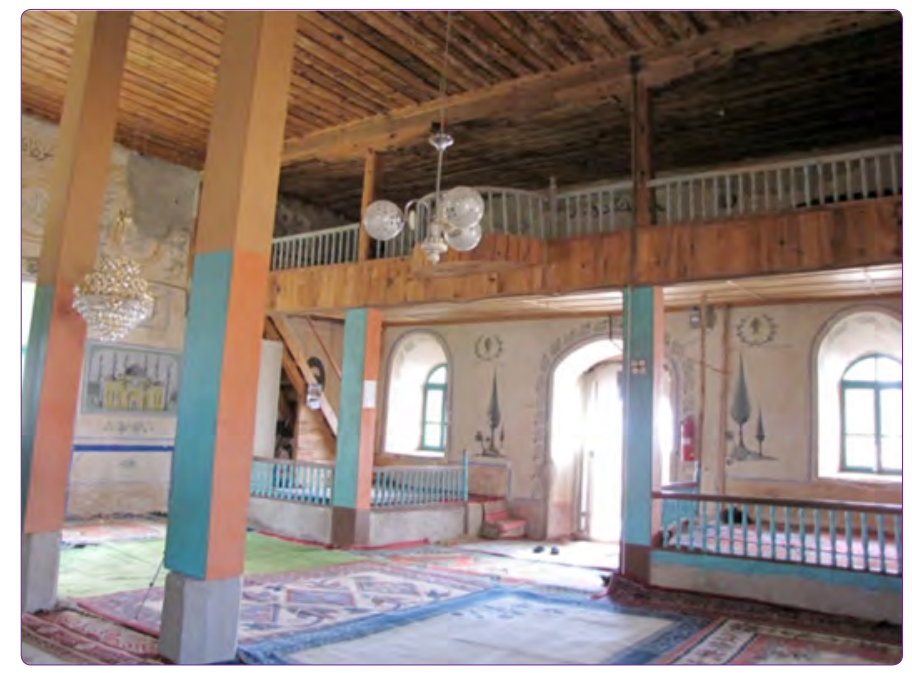

Şekil 37. Giriş kapısının her iki yanında bulunan servi ağaçları resimleri (Fotoğraf: Zeynep Gül Ünal).

Kapının her iki yanına bulunan doğal taş söveli muhdes demir parmaklıkların üzerlerinde boyanarak kapatılmış olan ve muhtemelen servi ağacı bezemesi olduğu düşünülen kalem işleri bulunmaktadır. Aynı şekilde kapının üzerinde de benzer şekilde üzeri boyayla kapatılmış servi ağacı bezemesi bulunmaktadır. Kapı ile solunda bulunan pencere arasında yine üzeri boya ile kapatılmıs bitkisel bir motif bulunmaktadır.

Kuzey duvarı (iç): Cami iç mekânı kuzey duvarında bulunan giriş kapısının etrafinı bitkisel bezeme çevrelemektedir. Kapının doğu ve batı tarafinda birer çelenk motifi bulunmaktadır. Bunun yanı sıra kapının her iki tarafinda büyük ve küçük serviden oluşan ayrıca küçük başka bir ağacın da bulunduğu bir betimleme vardır.

Giriş kapısının üzerinde bulunan Osmanlıca Türkçesi ile yazılmış beyitte, "O ( $\mathrm{Hz}$. Muhammed) öyle bir peygamber, öyle bir Nebî-î muhterem ve Resûl-ı müctebâ ki yeryüzü 'Resûlullah bende' diye göklere övünür" şeklinde Türkçeye çevrilebilecek bir ifade ile Arapça yazılmış olan "Hâzihî Cennâtü Adnin fedhulûhâ hâlidîn", Türkçe tercümesiyle; "Burası Adn cennetleridir, buraya ebedî kalacak şekilde girin" ifadesi müminlere girdikleri mekânın cennet olduğunu hatılatmakta, dolayısıyla içerdeki bezeme programının da bu ifade doğrultusunda planlandığını göstermektedir. İslâmiyet'in ilk yıllarından beri, en kutsal mekân olan cami harimleri, ahirette vaat edilen cennetin yeryüzündeki izdüşümü gibi algılanabilmektedir. ${ }^{34}$ Bunun bir sonucu olarak, giriş kapısının her iki yanında bulunan servi ağaçları resimleri anlamsal değer kazanır ve ibadete gelen mümin bu servi ağaçlarının arasından geçerek cennete ilk adımını attğı düşünülebilir (Şekil 37, 38). Servi ağaçlarının simetrisi başka bir sembolle, müsennâvav (çifte vav) ile devam eder.

\footnotetext{
${ }^{34}$ Okçuoğlu, 2000, s. 33.
}

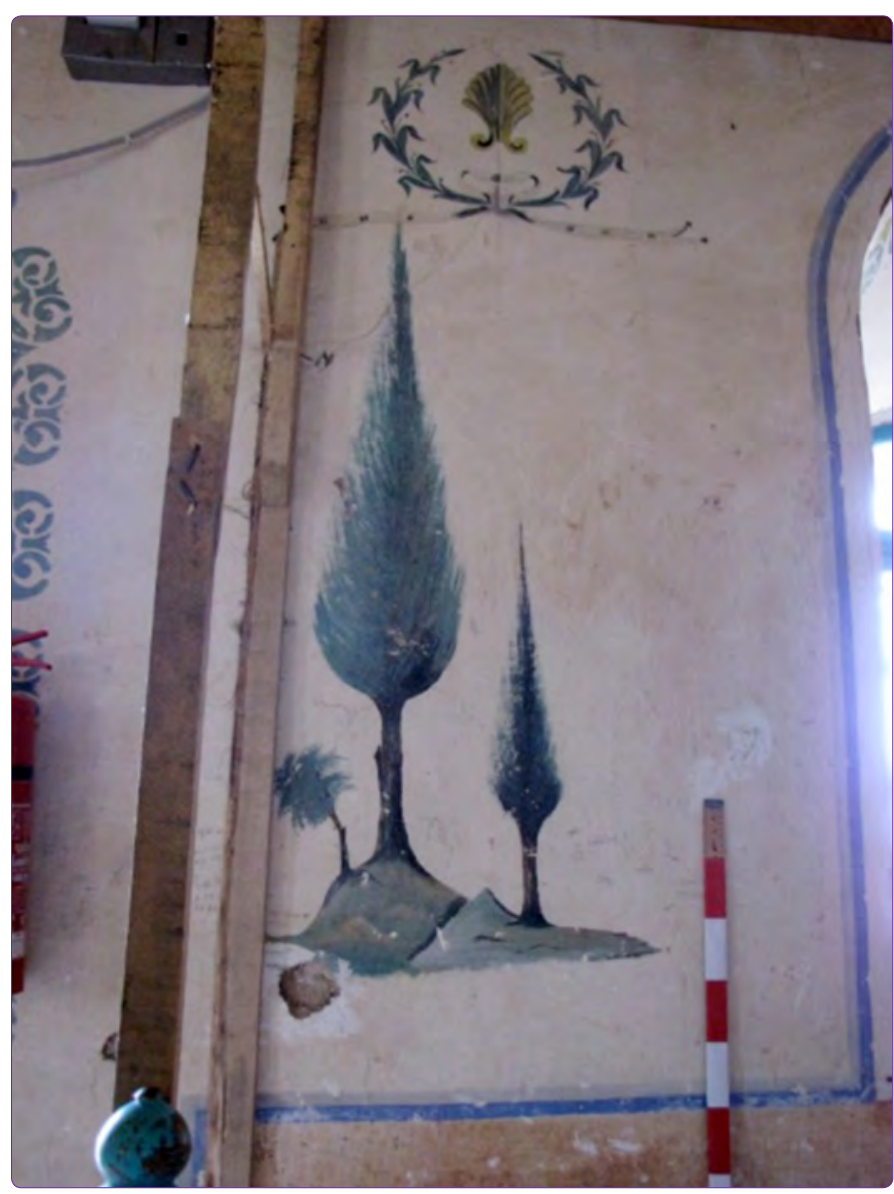

Şekil 38. Giriş kapısının yanındaki servi ağacı resmi (Fotoğraf: Zeynep Gül Ünal).

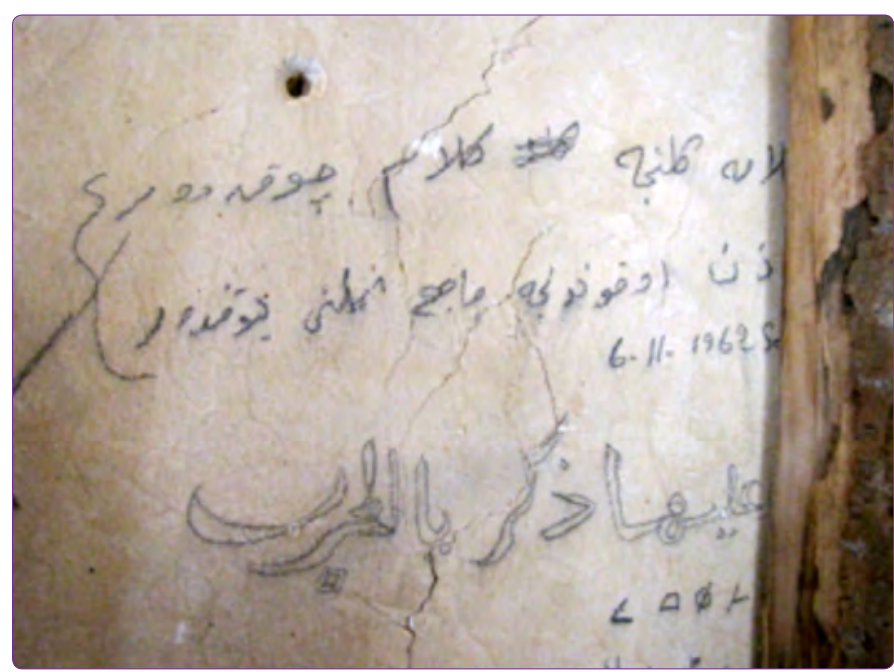

Şekil 39. Cami iç duvarlarındaki grafitiler (duvar yazısı) (Fotoğraf: Zeynep Gül Ünal).

Doğu ve batı duvarlarında cami giriş kapısına çok yakın olarak çifte vavlar bulunmaktadır. Bilindiği üzere, vav harfi Sufiler arasında önemli anlamları sembolize eder. Tümeldeki (küll) mutlak yöne vav denir. Bakara Sûresi'nin 115. ayetine işaret eder: "Nereye yönelirseniz, Allah'ın vechi oradadır". 
Ebced hesabında ise, vav harfinin değeri altıdır. Bu altı sayısının da altı yöne işaret ettiği düşünüldüğü gibi imanın alt şart da kastedilir. Osmanlı hat sanatında önemli bir yeri olan vav harfi anne rahmindeki çocuğa ve secde halindeki insana benzemesiyle sadakat ve tevazu, ilk harfi olduğu Allah'ın "vahdaniyet" sıfat ve "vahid" ismini simgeler. Ayrıca bu çifte vavlar, ebced hesabına göre 66'ya tekabül eder ki bu da Allah lafzına karşılık gelir..$^{35}$ Bu bilgiler ışığında mekânın; giriş kapısının iki yanındaki servi ağaçları, giriş kapısına çok yakın bulunan çifte vavlar ve yazılarla birlikte bütüncül olarak cennet ile sembolize edildiği söylenebilir. Camiye giren kişi ileri doğru baktığında güney cephesinde isimleri zikredilen aşare-i mübeşşere ile karşılaşır. İbadet eden kişi, belki de bu isimleri görerek cennete girebilmek için ibadetini daha da şevkle yapacaktır. Bununla beraber güney duvarında Allah'ın merhameti Yusuf Sûresi'nin 64. ayeti ile hatılatılırken, başarının ve zaferinden ancak ondan geldiği Fetih Sûresi'nin birinci ve Hud Sûresi'nin 88 . ayeti ile hatırlatılır. Kuşkusuz yirminci yüzyılın başlarında bu yazılar Osmanlı tebaası olan Müslümanların manevi dünyalarında pek çok anlam ifade ediyor olmalıdır. ${ }^{36}$

Ayrıca caminin içinde duvarların çeşitli yerlerinde grafiti olarak (duvar yazısı) Osmanlıca, Latin harfli Türkçe metinler ve Arapça yazılmış ifadeler bulunmaktadır (Şekil 39). Bu duvar yazılarının cami yapıldıktan sonra çeşitli zamanlarda yazıldığı düşünülmektedir. Bunların bazılarında tarih de bulunmaktadır. Bu yazılar camiye sonradan eklenmiş olmalarına rağmen, belge değeri taşımaları nedeniyle son derece önemlidir.

\section{Sonuç}

Sahip olduğu tarihi ve mimari nitelikleri sebebiyle tescillenerek koruma altnna alınan Bademli Camisi, yoğun bir bezeme programına sahip olması ve bezemelerinin özgün niteliklerini koruması açısından önemli bir örnek teşkil etmektedir. Özellikle camide bulunan kalem işi Osmanlı arması caminin tarihi önemini daha da artırmaktadır. Ayrıca caminin giriş kapısından içeriye doğru devam eden yazı programı, 20. yüzyıl başında mekândaki ibadetin sembolik yansımasının nasıl algılandığını göstermesi açısından son derece ilgi çekicidir.

Bademli Camisi hem bakım ve onarım eksikliğine hem de kullanıma bağlı koruma sorunları yaşamaktadır. Örneğin, kadınlar mahfilinin yapıya sonradan eklenmesi, içerdeki duvar resimlerinin bütünlüğünü önemli derecede bozmaktadır. Bademli Camisi'nin sahip olduğu özgün niteliklerin korunması için makale yazarları tarafindan 2018 yı- lında hazırlanan koruma projesinde de belirtildiği gibi; yapının taşıyıcı sisteminin en kısa zamanda iyileştirilmesi ve en önemli belgeleri oluşturan kalem işi bezemelerin özgün niteliklerini koruyacak şekilde temizleme, tamamlama vb. müdahaleler yapılmadan korunması önerilmektedir.

Not: Yıldız Teknik Üniversitesi, Mimarlık Fakültesi, Restorasyon Yüksek Lisans Programı Koruma Projesi kapsamında 2011 Bahar yarıyılında Zeynep Gül Ünal danışmanlığında Aslıhan Ece Paköz tarafindan hazırlanan Bademli Cami koruma projesi, Bademli Kaymakamlığı'nın bu projeyi kullanmaya yönelik isteği üzerine sosyal sorumluluk projesi kapsamında Ocak 2018 tarihinde güncellenmiştir. Makalede bu koruma projesinden yararlanılmıştı. Makalede kullanılan tüm fotoğraflar Mart 2011'de yazarlardan Zeynep Gül Ünal tarafindan çekilmiştir. Yapının rölöve ölçüleri yazarlar Zeynep Gül Ünal ve Aslıhan Ece Paköz tarafindan Mart 2011'de alınmıştır.

\section{Kaynaklar}

Arık, R. (1988) Battlılaşma Dönemi Anadolu Tasvir Sanat, Ankara, Kültür ve Turizm Bakanlığı Yayınları.

Derman, M. Uğur (1967) "Hâfiz Osman'ın Hat Sanatımızdaki Yeri", Hayat, İstanbul, Sayı 52, s. 8-9.

Durmuş, i. (2012) "Vav", İslam Ansiklopedisi, 2012, s. 574-576.

Hatipoğlu, O. (2007) "XIX. Yüzyıl Osmanlı Camilerinde Kalem İşi Tezyînât", Basılmamış Doktora Tezi, Atatürk Üniversitesi, Sosyal Bilimler Enstitüsü.

Kur'ân-ı Kerîm ve Türkçe Anlamı (Meâl) (1985), Ankara, Diyanet İşleri Başkanlığı Yayınları.

Okçuoğlu, T. (2000) “18. ve 19. Yüzyıllarda Osmanlı Duvar Resimlerinde Betimleme Anlayışı", Basılmamış Doktora Tezi, İstanbul Üniversitesi, Sosyal Bilimler Enstitüsü.

Renda, G. (1977) Bathlılaşma Döneminde Türk Resim Sanat 17001850, C-17, Ankara, Hacettepe Üniversitesi Yayınları.

Şener, D. (2011) “XVIII. ve XIX. Yüzyıllarda Anadolu Duvar Resimleri", Basılmamış Doktora Tezi, Ankara Üniversitesi, Sosyal Bilimler Enstitüsü.

Tali, Ş. (2013) “Kırşehir/Mucur'daki Hüseyin Ağa Camii ile Emine Hanım Camii'nin Kalemişleri", Uluslararası Sosyal Araştırmalar Dergisi, Sayı, 25, s. 504-528.

Tekinalp, P.Ş. (2002) "Batlılaşma Dönemi Duvar Resim Sanatı 1700-1850", Türkler Ansiklopedisi, Ankara, Yeni Türkiye Yayınları, Cilt 15, s. 718-730.

Yelen, R. (2017) "islam Sanatnda Süsleme Sembolizmi Üzerine Yeni Yorumlar", Van Yüzüncü Yıl Üniversitesi Sosyal Bilimler Enstitüsü Dergisi, Sayı: 2, s.470-492.

\section{İnternet Kaynakları}

https://biruni.tuik.gov.tr/medas/?kn=95\&locale=tr [Erişim tarihi 30 Nisan 2020]
35 Durmuş, 2012, s. 574-576.

${ }^{36}$ Osmanlı tebaasının İslâm anlayışı hakkında ayrıntılı bilgi için bkz.: Ha- tice K. Arpaguş, Osmanlı Halkının Geleneksel İslâm Anlayışı ve Kaynakları, İstanbul: IFAV, 2015. 